dr hab. inż. Władysław Harmata, prof. WATa)*, gen. bryg. rez. Marek Witczak, prof. wizyt. WATª), ppor. mgr inż. Grzegorz Pietrzaka)

a) Wojskowa Akademia Techniczna / Military University of Technology

*Autor korespondencyjny / Corresponding author: wladyslaw.harmata@wat.edu.pl

\title{
Koncepcja rozwiązań technicznych systemu powietrznego wykrywania skażeń wykorzystującego statki bezzałogowe
}

\author{
The Concept of Technical Solutions for an Air Contamination Detection System Using \\ Unmanned Vessels
Концепция технических решений для воздушной системы обнаружения загрязнений, использующей беспилотные летательные аппараты

\begin{abstract}
ABSTRAKT
Cel: Celem artykułu jest przedstawienie koncepcji rozwiązań technicznych systemu rozpoznawania skażeń wykorzystujących platformy bezpilotowe. Wprowadzenie: Obecnie rozpoznawaniem skażeń w strefie skażenia najczęściej zajmują się patrole piesze, które są zaopatrzone w odpowiednie przyrządy i postępują zgodnie z określonymi procedurami. Ich działania wymagają odpowiedniego wyposażenia w środki ochrony indywidualnej i likwidacji skażeń'. Głównymi czynnikami pośrednio lub bezpośrednio powodującymi uwolnienie materiałów niebezpiecznych i powstanie skażeń na terytorium Rzeczpospolitej Polskiej (RP) mogą być: działania militarne, katastrofy, awarie techniczne zakładów przemysłowych oraz terroryzm. Strategia bezpieczeństwa narodowego Rzeczypospolitej Polskiej [1], zbieżna z Europejską strategią bezpieczeństwa [2], jako główne zagrożenia dla bezpieczeństwa RP w XXI wieku wymienia m.in.: terroryzm, proliferację broni masowego rażenia (BMR), przestępczość zorganizowaną, awarie przemysłowe, klęski żywiołowe i katastrofy. Zagrożenia te uwzględniono na powyższej liście m.in. dlatego, że pod ich wpływem (pośrednio lub bezpośrednio) może dojść do chemicznego, biologicznego lub promieniotwórczego skażenia ludzi i środowiska. Współcześnie rozpoznanie skażeń powinno przebiegać automatycznie, obejmować duże odległości i odbywać się najlepiej bez udziału ludzi - tak jak to preferuje się w systemach rozpoznania skażeń np. w siłach zbrojnych USA. W Siłach Zbrojnych Rzeczypospolitej Polskiej (SZ RP) system rozpoznania skażeń oparty jest na procedurach i wyposażeniu technicznym pochodzących z połowy ubiegłego wieku. Jedną z możliwości praktycznego rozwiązania tego problemu jes zastosowanie bezzałogowych statków powietrznych (BSP). W niniejszym artykule skupiono się na koncepcji rozwiązań technicznych wykorzystujących mini-BSP. Wnioski: Zagrożenie skażeniami na terytorium RP nadal istnieje i ma tendencję zwyżkową. System wykrywania skażeń w SZ RP jest technicznie przestarzały i nie spełnia współczesnych wymagań. Wykorzystanie bezzałogowych statków powietrznych podczas powietrznego rozpoznania i wstępnej identyfikacji skażeń w znacznym stopniu mogłoby zwiększyć efektywność działania podsystemu rozpoznania skażeń w SZ RP, który funkcjonalnie wchodzi w skład Krajowego Systemu Wykrywania Skażeń i Alarmowania (KSWSiA). Do głównych zalet wykorzystania BSP w systemie rozpoznania powietrznego można zaliczyć m.in. brak konieczności narażania personelu na skażenie, ich dużą mobilność i manewrowość, a także możliwość prowadzenia działań w trudnych warunkach terenowych i nad zbiornikami. W skład BSP przeznaczonych do rozpoznania skażeń powinny wchodzić pododdziały rozpoznania skażeń Wojsk Chemicznych i Centralnego Ośrodka Analizy Skażeń.

Słowa kluczowe: rozpoznanie skażeń, bezzałogowe statki powietrzne

Typ artykułu: artykuł przeglądowy
\end{abstract}

Przyjęty: 02.03.2017; Zrecenzowany: 03.10.2017; Opublikowany: 29.12.2017;

Autorzy wnieśli równy wkład merytoryczny w powstanie artykułu;

Proszę cytować: BiTP Vol. 48 Issue 4, 2017, pp. 14-32, doi: 10.12845/bitp.48.4.2017.1;

Artykuł udostępniany na licencji CC BY-NC-SA 4.0 (https://creativecommons.org/licenses/by-nc-sa/4.0/).

\section{ABSTRACT}

Aim: The aim of the paper is to present the concept of technical solutions for contamination reconnaissance based on pilotless devices Introduction: Nowadays, contamination detection in contaminated zones is mostly performed by foot patrols, which are equipped with devices and follow specific procedures. They need appropriate personal protective equipment as well as decontamination devices ${ }^{2}$. The main factors which can

\footnotetext{
Rozpoznanie skażeń, identyfikacja skażeń i monitoring - przedsięwzięcia niezbędne do wykrycia uderzeń BMR i zdarzeń typu ROTA (release other than attack - uwolnienie inne niż atak) oraz do oceny ich skutków poprzez rozpoznanie i identyfikację występujących skażeń, określenie stopnia skażenia, wyznaczenie granic rejonów skażonych, pobranie próbek oraz monitorowanie zmian w sytuacji skażeń [doktryna DD-3.8(A), sygn. Szkol. 869/2013].

2 Contamination detection, identification and monitoring - are the measures necessary to detect WMD and ROTA events (release other than attack) and to assess their effects by way of detecting and identifying contamination, their degree, the boundaries of contaminated areas, taking samples and monitoring the changes in the contaminated environment [doctrine DD-3.8 (A), no. Szkol. 869/2013]
} 
directly or indirectly cause the release of hazardous materials and lead to the contamination at the territory of the Republic of Poland (RP) are military actions, disasters, plant failures as well as terrorism. The National Security Strategy of the Republic of Poland [1], convergent with the European Security Strategy [2], lists the following among the main threats for Poland's security in the second half of the $21^{\text {st }}$ century: terrorism, proliferation of weapons of mass destruction, organized crime, industrial failures, natural tragedies and disasters. One of the reasons why these threats are present in this list is the possibility of their leading, directly or indirectly, to the chemical, biological and radioactive contamination of people and environment. Nowadays, contamination detection should be performed automatically, at large distances, if possible without the involvement of people, e.g. such as in the contamination detection systems of the US Armed Forces. In the Armed Forces of the Republic of Poland, the contamination detection system is based on procedures and technical equipment dating back to the 1950s. One practical solution to this problem is the application of Unmanned Aerial Vehicles (UAV). In this article, the main focus is on the technical solutions incorporating mini-UAVs.

Conclusions: The threat of contamination of the territory of Poland still exists and its risk is increasing. The contamination detection system of the Polish Armed Forces is obsolete and does not meet contemporary requirements. The use of Unmanned Aerial Vehicles for the aerial reconnaissance and initial identification of contaminants can significantly increase the efficiency of the operation of the Polish Armed Forces contamination detection sub-system which is functionally included in the National System for Contaminants Detection and Alerting. The main advantages of the UAV use in aerial reconnaissance are: no need for human presence, high mobility and maneuverability and the possibility of operation in difficult terrain conditions as well as over water bodies. UAVs in their contamination detection versions should be incorporated into contamination detection subdivisions of the Chemical Forces and the Central Station of Contamination Analysis.

Keywords: contamination reconnaissance, unmanned aircraft

Type of article: review article

Received: 02.03.2017; Reviewed: 03.10.2017; Published: 30.12.2017;

The authors contributed equally to this article;

Please cite as: BiTP Vol. 48 Issue 4, 2017, pp. 14-32, doi: 10.12845/bitp.48.4.2017.1;

This is an open access article under the CC BY-NC-SA 4.0 license (https://creativecommons.org/licenses/by-nc-sa/4.0/).

\section{АННОТАЦИЯ}

Цель: Цель статьи - представить концепцию технических решений для системы обнаружения загрязнений, использующих беспилотные платформы.

Введение: В настоящее время обнаружение загрязнений в зоне загрязнения чаще всего осуществляется пешими патрулями, которые оснащены соответствующими приборами и действуют в соответствии с определенными процедурами. Их деятельность требует соответствующего оснащения для индивидуальной защиты и ликвидации загрязнений ${ }^{3}$. Основными факторами, которые непосредственно или посредственно вызывают выброс опасных материалов и загрязнения на территории Республики Польша, могут быть: военные действия, катастрофы, технические аварии промышленных заводов, а также терроризм. Стратегия народной безопасности Республики Польша [1], совпадающая с Европейской стратегией безопасности [2], в качестве главных угроз для безопасности Польши в XXI веке перечисляет в частности: терроризм, распространение ядерного оружия, организованную преступность, промышленные аварии, стихийные бедствия и катастрофы. Эти угрозы были учтены в вышеуказанном списке между прочем потому, что под их влиянием (посредственно или непосредственно) может произойти химическое, биологическое или радиационное загрязнение людей и окружающей среды. В настоящее время обнаружение загрязнений должно происходить автоматически, охватывать большие территории и не требовать участия людей - так, как это предпочтительно для систем обнаружения загрязнений в вооруженных силах США. В вооруженных силах Республики Польша система обнаружения загрязнений основана на процедурах и техническом оборудовании с середины прошлого века. Одной из возможностей практического решения этой проблемы является применение беспилотных летательных аппаратов (БЛА). В настоящей статье основное внимание было посвящено концепции технических решений, использующих мини-БЛА

Выводы: Угроза загрязнений на территории Польши все еще существует и имеет растущую тенденцию. Система обнаружения загрязнений в вооруженных силах Польши технически устарела и не соответствует современным требованиям. Использование беспилотных летательных аппаратов во время воздушной разведки и вступительной идентификации загрязнений в значительной степени могло бы улучшить эффективность действия подсистемы обнаружения загрязнений в вооруженных силах Польши, которая функционально входит в состав Национальной Системы Обнаружения Загрязнений и Тревоги. К основным преимуществам использования БЛА в системе воздушной разведки можно причислить в частности: отсутствие необходимости подвергнуть персонал угрозе заражения, высокую мобильность и маневренность БЛА, а также возможность проводить действия в сложных полевых условиях и над водоемами. В состав БЛА, предназначенных для обнаружения загрязнений, должны входить подразделения обнаружения загрязнений Химических войск и Центрального Центра Анализа Загрязнений.

Ключевые слова: обнаружение загрязнений, беспилотные летательные аппараты

Вид статьи: обзорная статья

Принята: 02.03.2017; Рецензирована: 03.10.2017; Опубликована: 30.12.2017;

Авторы внесли одинаковый вклад в создание этой статьи;

Просим ссылаться на статью следующим образом: BiTP Vol. 48 Issue 4, 2017, pp. 14-32, doi: 10.12845/bitp.48.4.2017.1;

Настоящая статья находится в открытом доступе и распространяется в соответствии с лицензией CC BY-NC-SA 4.0 (https://creativecommons.org/ licenses/by-nc-sa/4.0/).

з Обнаружение загрязнений, идентификация загрязнений и мониторинг - мероприятия необходимые для обнаружения ударов орудия массового уничтожения и выбросов, не связанных со взрывом/атакой, а также для оценки их последствий посредством разведки и идентификации имеющихся загрязнений, определения уровня загрязнения, определения границ загрязненных районов, отбора образцов и мониторинг изменений в ситуации загрязнения [доктрина DD-3.8(A), cигн. Szkol. 869/2013]. 


\section{Analiza zagrożenia skażeniami na terytorium RP}

Wielowymiarowość zagrożeń sprawia, że w literaturze możemy znaleźć szereg kryteriów, według których autorzy starają się te zagrożenia usystematyzować. Wśród nich są kryteria: podmiotowe, przedmiotowe, zasięgu, skali. Najczęściej stosowane jest kryterium podmiotowe, które pozwala wyróżnić 5 rodzajów zagrożeń: polityczne, militarne, gospodarcze, społeczne (społeczno-kulturowe) i ekologiczne [3].

Niebezpieczeństwo uwolnienia substancji niebezpiecznych (np. TSP $)$ powodujących skażenie terenu może wystąpić nie tylko podczas procesów ich produkcji czy magazynowania, ale także w trakcie ich transportu. Wypadki i katastrofy komunikacyjne stanowią największy odsetek wydarzeń, w wyniku których dochodzi do skażenia środowiska substancją niebezpieczną. Największe zagrożenie to uwolnienie transportowanej substancji niebezpiecznej na obszarze miejskim. Ze względu na duże zaludnienie takiego obszaru zdarzenie to może skutkować dużą liczbą ofiar.

W Polsce substancje niebezpieczne stanowią 10\% (około 180 mln ton w 2014 r.) [4] wszystkich towarów przewożonych transportem lądowym. Pierwsze miejsce zajmuje transport samochodowy. W 2013 roku na naszych drogach rejestrowano codziennie średnio 2 tys. ciężarówek przewożących łącznie około 42 tys. ton chemikaliów [5]. Szacuje się także, że w ciągu doby przez polskie miasta przejeżdża średnio 40 ładunków $z$ materiałami niebezpiecznymi o masie od 5 do 20 ton. Brak wyznaczonych tras przewozu, zły stan techniczny pojazdów oraz nawierzchni dróg sprawiają, że samochody przewożące materiały niebezpieczne są w RP najbardziej ryzykownym środkiem transportu lądowego. Drugie miejsce zajmuje transport kolejowy. Według Głównego Urzędu Statystycznego w 2010 roku koleją przewieziono około 22,1 mln ton chemikaliów, z czego około $70,6 \%$ stanowiły benzyna i olej napędowy; $12,2 \%$ - gazy techniczne, a 7,6\% - substancje żrące [6]. Należy jednak zauważyć, że masy jednostkowe materiałów niebezpiecznych transportowane wagonami są dużo większe niż masy jednostkowe materiałów niebezpiecznych przewożone transportem drogowym, co sprawia, że ich uwolnienie może doprowadzić do skażenia znacznie większego obszaru środowiska.

W 2013 roku Główny Inspektor Ochrony Środowiska (GIOS) zarejestrował 84 zdarzenia z udziałem substancji niebezpiecznych. Spośród tych zdarzeń 55 miało miejsce w zakładach przemysłowych, a $21-w$ transporcie. Z kolei 12 zdarzeń GIOS zakwalifikował jako poważne awarie przemystowe (ryc. 1).

Warto zwrócić uwagę na to, że na obszarze RP oprócz ryzyka wystąpienia skażeń chemicznych istnieje także ryzyko wystąpienia skażeń radiacyjnych związanych z awariami obiektów energetyki jądrowej. Katastrofa w Czarnobylu w 1986 roku oraz katastrofa w Fukushimie w roku 2011 pokazały, że uwolnione w wyniku awarii szkodliwe izotopy promieniotwórcze, po dostaniu się do atmosfery oraz wód powierzchniowych, mogą być przenoszone na bardzo duże odległości od miejsca katastrofy. Polska nie ma elektrowni jądrowej. Główne zagrożenie dla niej stwarzają jednak elektrownie znajdujące się na terytoriach państw sąsiednich. Obecnie w promieniu $300 \mathrm{~km}$ od granic RP jest 9 elektrowni wytwarzających łącznie 15 GWe (Gigawatt - Electric) mocy energetycznej, w których pracują 24 reaktory jądrowe. Ich awaria może nastąpić m.in. w wyniku skutków klęski żywiołowej oraz działań terrorystycznych (ryc. 2).

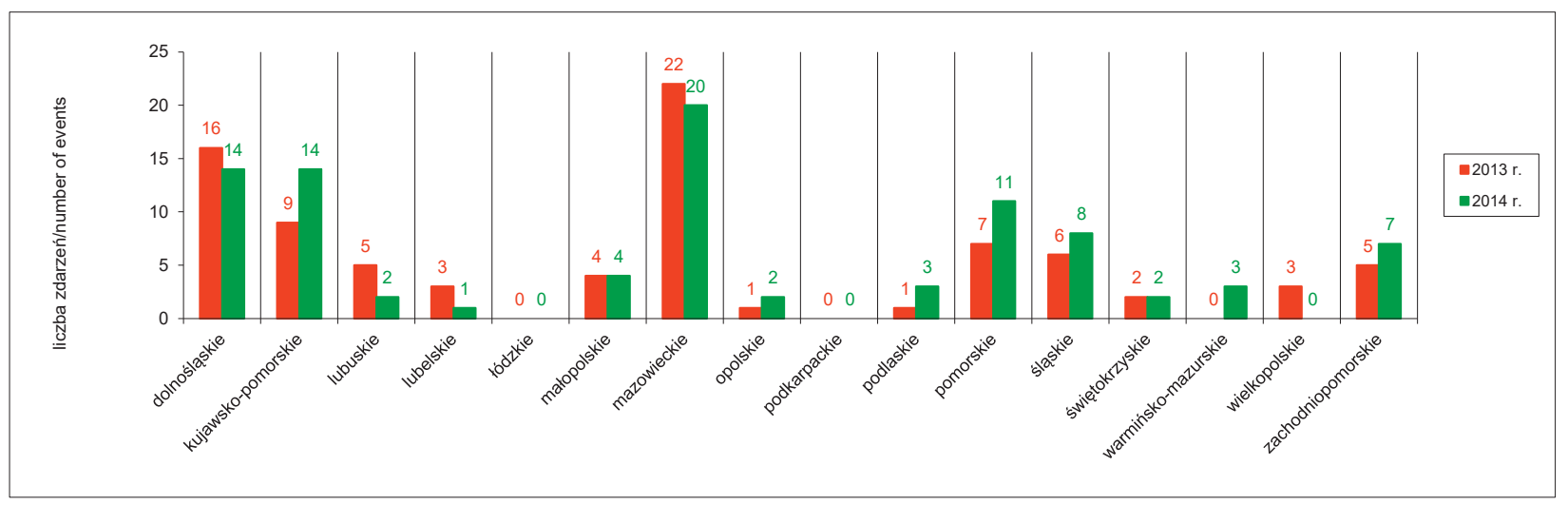

Rycina 1. Liczba zdarzeń z udziałem substancji niebezpiecznych w poszczególnych województwach w latach 2013 i 2014 [7]

Figure 1. The number of events involving dangerous substances in individual voivodships in 2013 and 2014 [7]

\footnotetext{
4 TSP (toksyczne środki przemysłowe) - substancje promieniotwórcze lub toksyczne w postaci stałej, ciekłej, gazowej lub aerozolowej, które mogą być używane albo stanowić zapas niezbędny do celów przemysłowych, handlowych, medycznych, wojskowych lub do użytku domowego. Toksyczne środki przemysłowe mogą być substancjami biologicznymi, chemicznymi oraz promieniotwórczymi i wtedy są opisywane jako toksyczne środki biologiczne, toksyczne środki chemiczne lub toksyczne środki promieniotwórcze (N0-01-A006:2011. Obrona przed bronią masowego rażenia. Terminologia).
} 


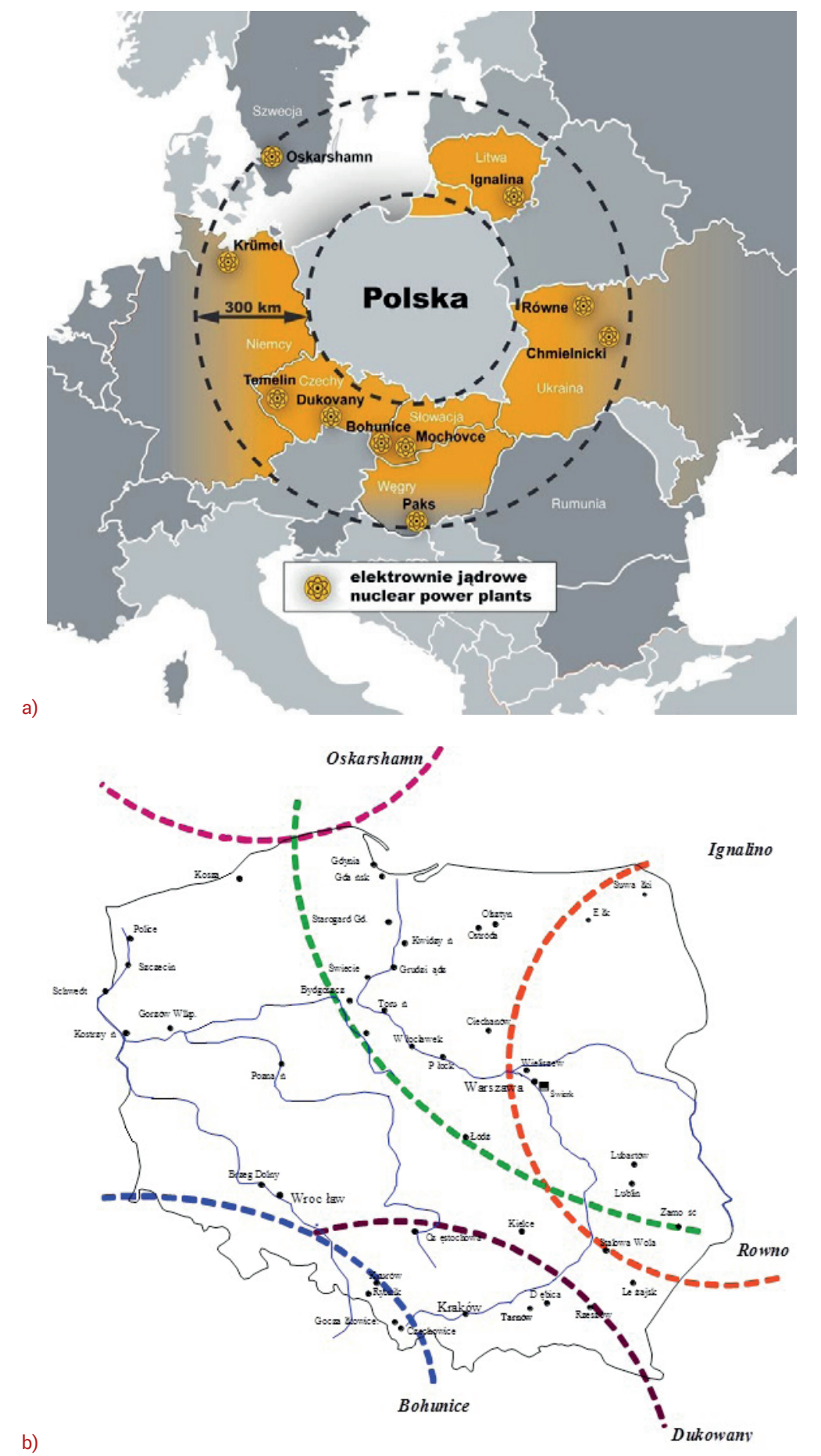

Rycina 2a. Czynne elektrownie jądrowe w odległości do $300 \mathrm{~km}$ od granic RP $[8,9]$

Rycin 2b. Prognozowane zasięgi skażeń w przypadku awarii reaktorów jądrowych $[8,9]$

Figure 2a. Active nuclear power plants located up to $300 \mathrm{~km}$ from Polish borders [8, 9]

Figure $\mathbf{2 b}$. Forecast contamination ranges in the case of nuclear reactor failures $[8,9]$

Bogata działalność wytwórcza człowieka sprzyja powstawaniu mniejszych lub większych zagrożeń dla środowiska. Trzeba jednak podkreślić, że problem ten jest bardzo trudny do rozwiązania, co wynika choćby z internacjonalizacji wielu dziedzin życia społecznego. Do niedawna niedoceniane kwestie zanieczyszczeń potęgują się i urastają do rangi problemu globalnego. W dzisiejszym uprzemysłowionym świecie paradoksem jest to, że skażenie powietrza i wód o wiele wyprzedza takie niebezpieczeństwa, jak skażenie żywności czy zagrożenie skutkami użycia broni masowego rażenia.

Zbyt późne wykrycie skażenia i podjęcie skutecznych działań zmierzających do jego likwidacji bardzo często powodują masowe straty - zarówno w ludziach, jak i w środowisku naturalnym (na ryc. 3 przedstawiono oddziaływanie związku 
somanu i Vx na człowieka w wyniku kontaktu z odkrytą skórą oraz odzieżą wierzchnią). Należy zatem prowadzić dokładną i systematyczną analizę realnych oraz możliwych przyczyn powstania skażeń, która pozwoli na szybkie wszczęcie działań umożliwiających uchronienie ludności przed skażeniami lub zminimalizowanie skutków tych skażeń. Jest to dość trudne zagadnienie ze względu na dużą złożoność przyczyn powstawania skażeń, których źródłem może być działalność człowieka lub niszczycielska siła natury. Obie te przyczyny są w pewnych aspektach ze sobą skorelowane, a wzajemnie na siebie wpływając, dodatkowo komplikują analizę zagrożenia skażeniami.

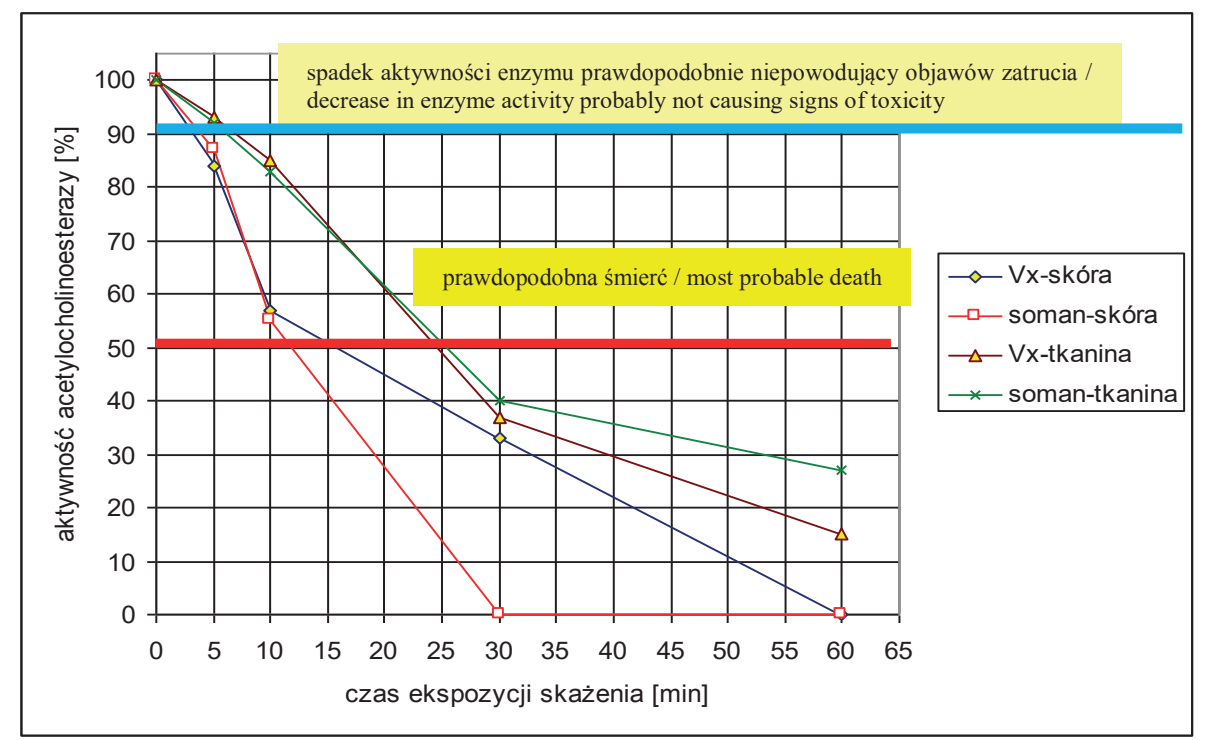

Czas ekspozycji skażenia - Time of exposure to contamination

Aktywność acetylocholinoesterazy - Activity of acetylocholinoesterase

Rycina 3. Spadek aktywności enzymu acetylocholinoesterazy u szczurów po skażeniu skóry i tkaniny bawełnianej somanem lub Vx (gęstość skażenia: ok. $\left.1 \mathrm{~g} / \mathrm{m}^{2}\right)$ [10]

Figure 3. A decrease in the activity of acetylocholinoesterase enzyme in rats after the contamination of the skin and cotton fabric with somane or $V x$ (density of contamination: ca. $1 \mathrm{~g} / \mathrm{m}^{2)}$ ) [10]

Wizja skażonego czy też silnie zatrutego środowiska budzi wiele obaw, tym bardziej że oprócz możliwych skażeń spowodowanych przez broń masowego rażenia w większości będą to skażenia wywołane przez toksyczne środki przemysłowe (TSP) uwolnione po awariach, uszkodzeniach albo zniszczeniach zakładów przemysłowych na terytorium danego kraju i na jego terenach przygranicznych.

Współcześnie, jak wspomniano wcześniej, zagrożenie może mieć źródło głównie w aktach terrorystycznych będących elementem działań asymetrycznych (w obecnym piśmiennictwie można spotkać określenie "działania hybrydowe").

\section{System wykrywania skażeń}

Wzrost zagrożenia, m.in. wymienionymi wcześniej czynnikami, sprawił, że w 2006 roku w RP utworzono Krajowy System Wykrywania i Analizowania Skażeń. System ten powstał z potrzeby skoordynowania działań różnych resortów administrujących własnymi systemami wykrywania skażeń. W jego ramach skoordynowane oraz interoperacyjne działania są prowadzone przez podsystemy funkcjonalne oraz jednostki organizacyjne układu militarnego i pozamilitarnego, wydzielane w ramach tzw. reagowania kryzysowego [11].
Krajowy System Wykrywania Skażeń i Alarmowania tworzą: Centrum Dyspozycyjne (CD) oraz wspomniane już podsystemy funkcjonalne i jednostki organizacyjne (ryc. 4). Zadaniem podsystemów jest wykrywanie skażeń i alarmowanie o nich. Z kolei jednostki organizacyjne zajmują się analizą skażeń i oceną sytuacji skażeń, na podstawie czego opracowują, ogłaszają i wszczynają działania interwencyjne. Wszystkimi działaniami w ramach systemu koordynuje Minister Obrony Narodowej przy pomocy Centrum Dyspozycyjnego.

Rdzeń KSWSiA tworzą systemy funkcjonalne, do których zalicza się m.in. System Wykrywania Skażeń SZ RP (nadzorowany przez Ministra Obrony Narodowej), systemy nadzoru epidemiologicznego (nadzorowane przez Ministra Zdrowia) oraz System Wykrywania Skażeń Promieniotwórczych (nadzorowany przez prezesa Państwowej Agencji Atomistyki - PAA). W skład KSWSiA wchodzą ponadto: organy i jednostki organizacyjne (ryc. 4) podejmujące działania interwencyjne w przypadku wystąpienia skażeń, nadzorowane przez właściwych ministrów oraz przez wojewodów; formacje OC (obrony cywilnej) zajmujące się monitoringiem, wykrywaniem i rozpoznaniem skażeń oraz alarmowaniem o nich; dyrektorzy urzędów morskich w zakresie swoich kompetencji dotyczących skażeń; inne organy i jednostki organizacyjne, które prowadzą obserwacje i pomiary skażeń, powiadamiają o skażeniach występujących na terenie kraju albo są włączone do systemów na podstawie umów i porozumień. 


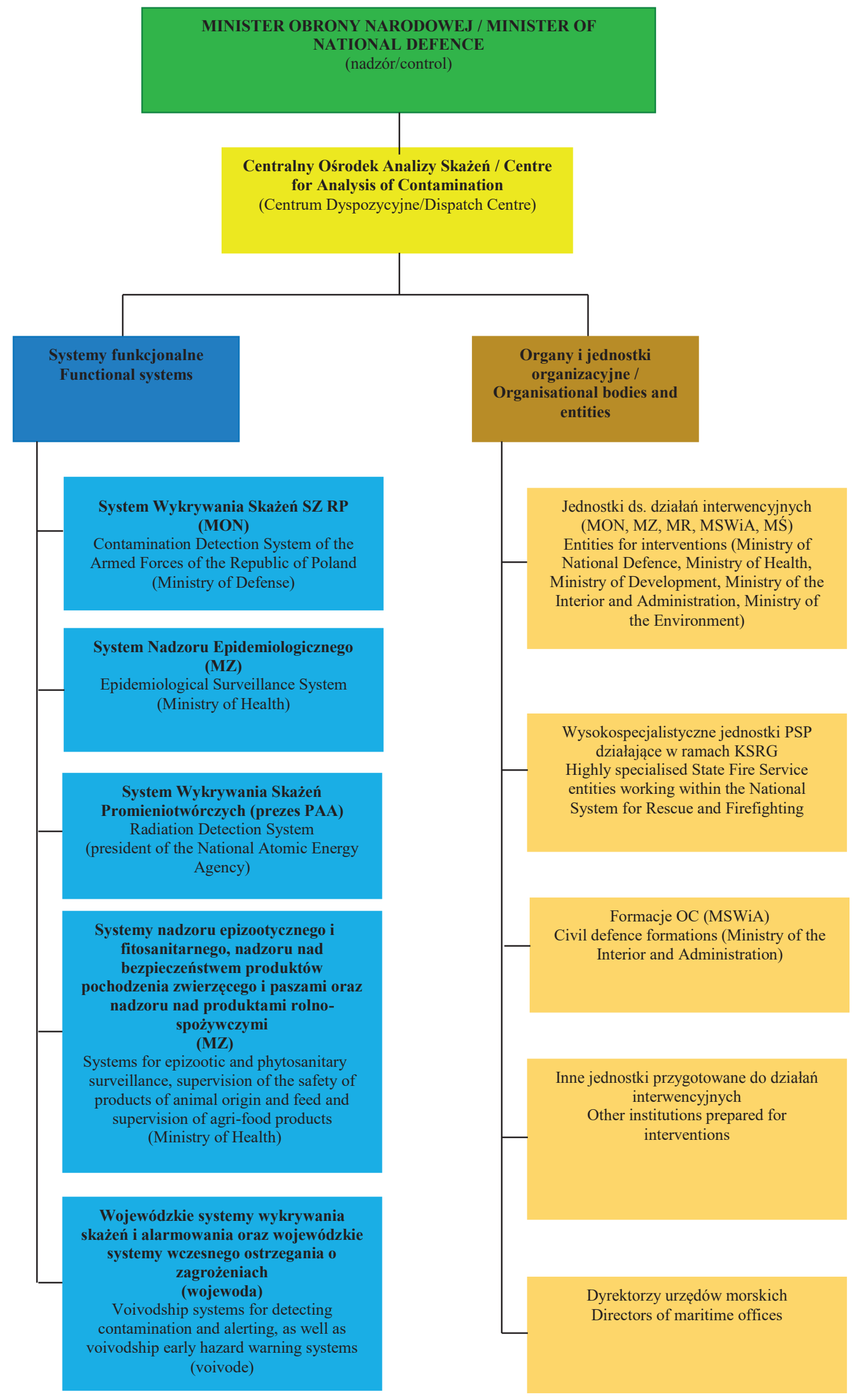

Rycina 4. Struktura Krajowego Systemu Wykrywania Skażeń i Alarmowania [12]

Figure 4. The structure of the National System for Contaminants Detection and Alerting [12] 
Na ryc. 5 przedstawiono obieg informacji w KSWSiA podczas zarządzania kryzysowego. Oprócz wyżej wymienionych systemów, organów i jednostek organizacyjnych bardzo ważnym elementem krajowego systemu jest Centrum Dyspozycyjne, które funkcjonuje w ramach Centralnego Ośrodka Analizy Skażeń (COAS) w Warszawie. Odpowiada ono za proces wymiany informacji pomiędzy wszystkimi elementami systemu, koordynację ich działań oraz opracowanie ocen i analiz eksperckich dotyczących stanu zagrożenia skażeniami. Oceny i analizy te są następnie przedstawiane organom decyzyjnym i służą za podstawę do podjęcia działań interwencyjnych. Dodatkowo COAS, jako CD, bierze udział w doskonaleniu KSWSiA m.in. poprzez przygotowywanie przedsięwzięć szkoleniowych oraz opracowywanie nowych rozwiązań proceduralnych i formalnoprawnych.

W 2013 roku, na podstawie doświadczeń wynikających z sześciu lat funkcjonowania KSWSiA, zaktualizowano podstawowy akt prawny regulujący jego działanie - rozporządzenie Rady Ministrów z dnia 7 stycznie 2013 roku w sprawie systemów wykrywania skażeń i powiadamiania o ich wystąpieniu oraz właściwości organów w tych sprawach [12]. Akt ten wprowadził wiele zmian w składzie omawianego systemu. Z KSWSiA wyłączono system wykrywania i alarmowania określony w Krajowym planie zwalczania zagrożeń i zanieczyszczeń środowiska morskiego. Podmiotami odpowiedzialnymi za problematykę dotyczącą skażeń na morzu uczyniono organy administracji morskiej, tj. urzędy morskie. W związku z regularnie pojawiającymi się zagrożeniami chorobami odzwierzęcymi (ptasia grypa, świńska grypa, pryszczyca itp.) do KSWSiA włączono systemy nadzoru epizootycznego i fitosanitarnego, nadzoru nad bezpieczeństwem produktów pochodzenia zwierzęcego i paszami oraz nadzoru nad produktami rolno-spożywczymi. Określono, że systemy te będą podlegać ministrom właściwym do spraw rolnictwa i rynków rolnych oraz zdrowia. Nowelizacja pozwoliła także dostosować zapisy rozporządzenia oraz KSWSiA do obowiązującej ustawy o zarządzaniu kryzysowym [13]. Nadała także Ministrowi Obrony Narodowej szczególne uprawnienia, którymi są nadzór nad KSWSiA oraz koordynacja jego działań przy pomocy CD COAS.

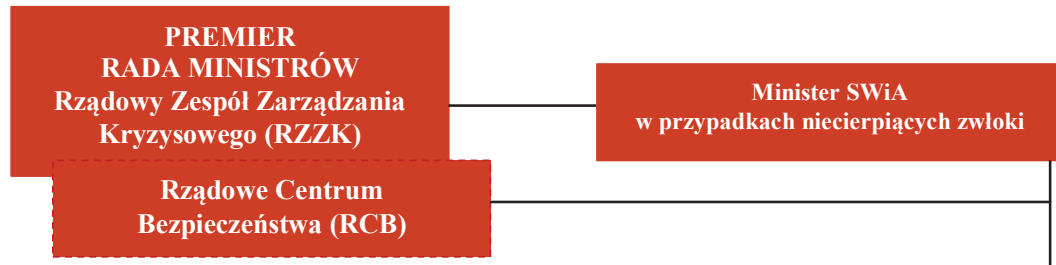

\begin{tabular}{|c|c|c|}
\hline $\begin{array}{c}\text { Centrum Dyspozycyjne KSWSIA } \\
\text { (COAS MON) }\end{array}$ & Dane meteorologiczne & $\begin{array}{l}\text { Instytut Meteorologii } \\
\text { i Gospodarki Wodnej }\end{array}$ \\
\hline
\end{tabular}

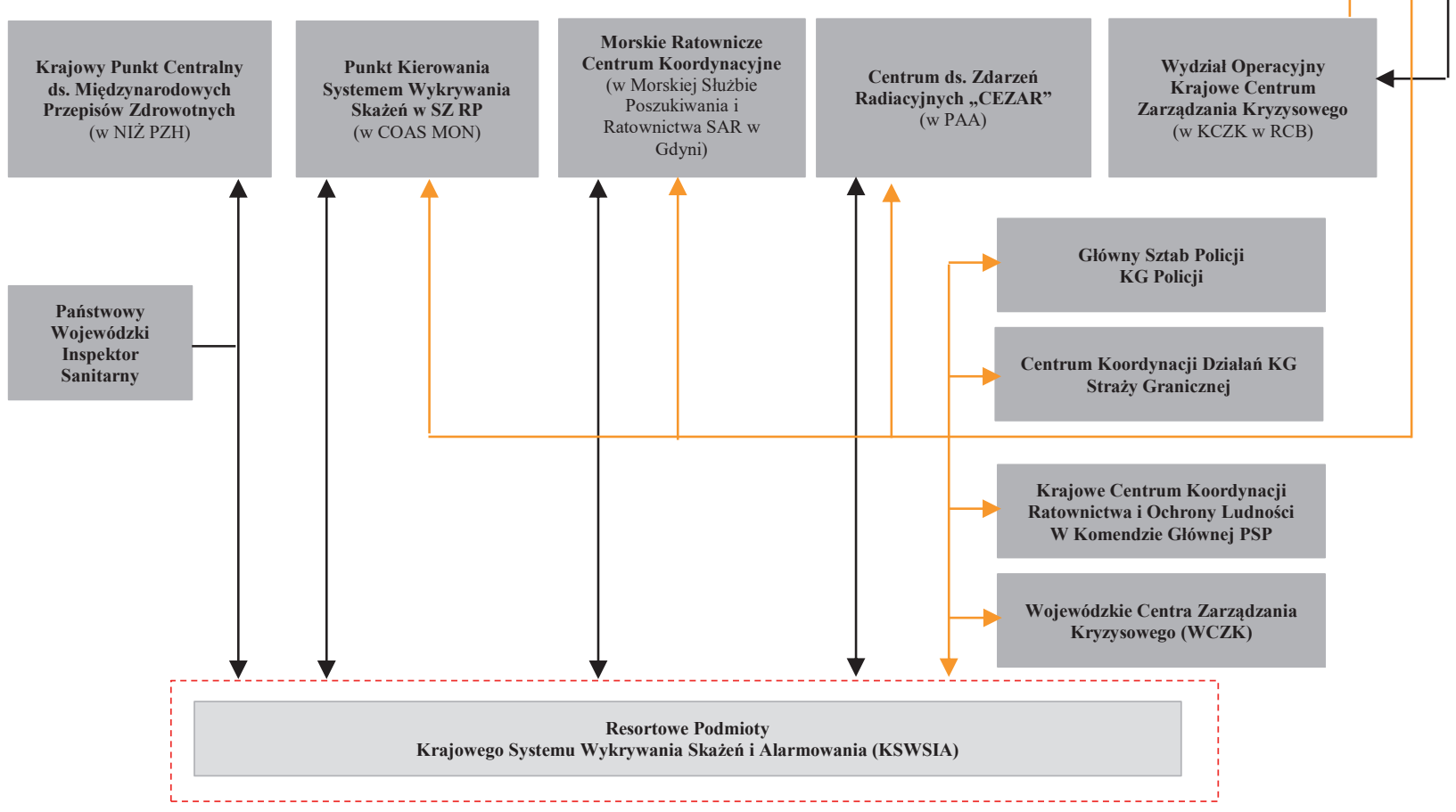

Rycina 5. KSWSiA w systemie zarządzania kryzysowego - obieg informacji [13] 


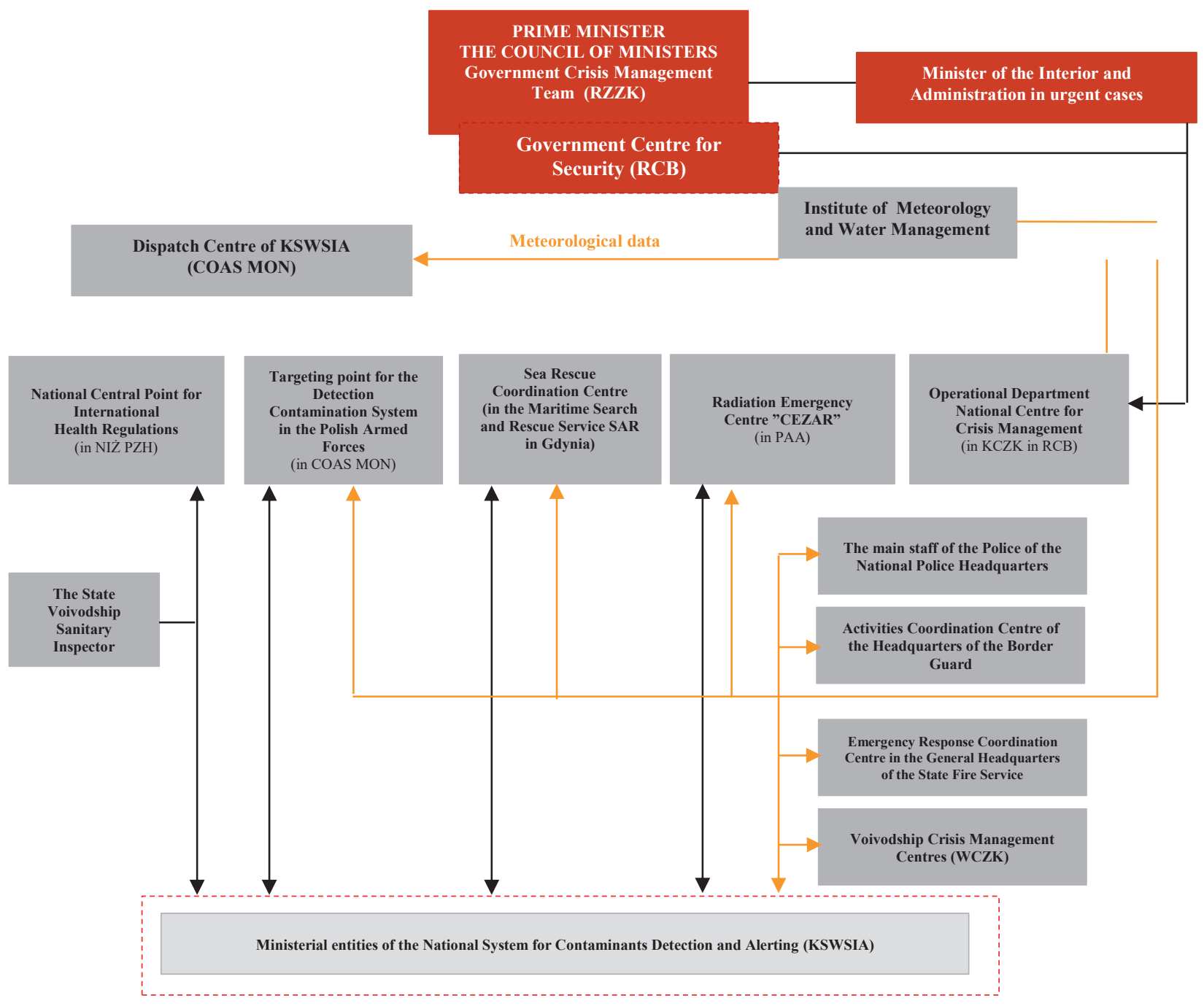

Figure 5. National System for Contaminants Detection and Alerting in crisis management - information flow [13]

Do głównych zadań KSWSiA należą [12]:

- realizacja zadań sojuszniczych oraz zobowiązań wynikających z ratyfikowanych porozumień międzynarodowych w zakresie obserwacji, pomiarów, analiz, prognozowania i powiadamiania o skażeniach na terytorium RP;

- monitorowanie wykrywanie i rozpoznanie skażeń umożliwiające natychmiastowe stwierdzenie wzrostu poziomu skażeń na podstawie standardów i norm krajowych;

- ostrzeganie i alarmowanie ludności lub SZ RP o skażeniach;

- opracowywanie ocen eksperckich stanu zagrożenia skażeniami i przygotowywanie zaleceń postępowania ochronnego;

- doradztwo specjalistyczne w zakresie metodyki ograniczania zasięgu i skutków oddziaływania skażeń;

- uruchamianie systemów wykrywania skażeń i systemów alarmowania o nich ludności lub SZ RP oraz inicjowanie działań interwencyjnych.

W państwach NATO system wykrywania skażeń opiera się głównie na zautomatyzowanych systemach wykorzystujących najnowsze technologie, w RP zaś - na patrolach pieszych i transporterach rozpoznania skażeń (BRDM-2rs). W Polsce w większości przypadków wyposażenie techniczne do wykrywania skażeń uwzględnia rozwiązania techniczne z połowy XX wieku. Nowe rozwiązania, dorównujące rozwiązaniom światowym, a często nawet je przewyższające, są dostępne, ale brakuje woli oraz funduszy, by je wdrożyć.

Do początku XXI wieku system powietrznego rozpoznania skażeń opierał się na etatowych pododdziałach powietrznego rozpoznania skażeń Sz RP. Tworzyły go załogi kluczy śmigłowców Mi-2rs "Padalec" wydzielane w ramach związków operacyjnych sił powietrznych, wojsk lądowych i marynarki. Od wycofania z użytkowania śmigłowców Mi-2rs (w ćwiczeniach wykorzystywano śmigłowce Mi-2Ch "Chekla", pierwotnie przeznaczone do stawiania zasłon dymnych i dodatkowo wyposażone w środki do rozpoznania skażeń promieniotwórczych) [15] SZ RP nie mają odpowiednich środków na prowadzenie powietrznego rozpoznania skażeń. To sprawia, że mimo wielu swoich zalet system powietrznego rozpoznawania skażeń w RP praktycznie nie istnieje, a obowiązujący system rozpoznania i identyfikacji skażeń opiera się głównie na siłach i środkach naziemnych [16]. 
Istotną zaletą powietrznego rozpoznania skażeń jest możliwość prowadzenia rozpoznania w miejscach o dużej mocy dawki (wysokim stężeniu), trudno dostępnych (nieprzejezdnych dla pojazdów naziemnego rozpoznania skażeń). Dodatkowymi zaletami są możliwość dostosowania się do warunków działania oraz niewielka zależność od warunków pogodowych i terenowych.

Powietrzne rozpoznanie skażeń jest wykorzystywane głównie w celu określenia sytuacji skażeń promieniotwórczych (granic skażonych terenów, mocy dawek promieniowania w ustalonych punktach oraz wysokości, szerokości i kierunku przemieszczania się obłoku promieniotwórczego) w rejonach działań militarnych (obecnych lub planowanych). Jest to możliwe dzięki temu, że podczas rozpoznania powietrznego ekspozycja załóg na promieniowanie jest znacznie bardziej ograniczona niż podczas rozpoznania naziemnego. Osiąga się to m.in. dzięki dużo większej manewrowości oraz szybkości prowadzenia rozpoznania powietrznego. Wykorzystując środki powietrzne, można dotrzeć do miejsc niedostępnych dla naziemnych pododdziałów rozpoznawczych i zbadać znacznie większy obszar, przy zachowaniu odległości od źródła skażenia (ryc. 6).

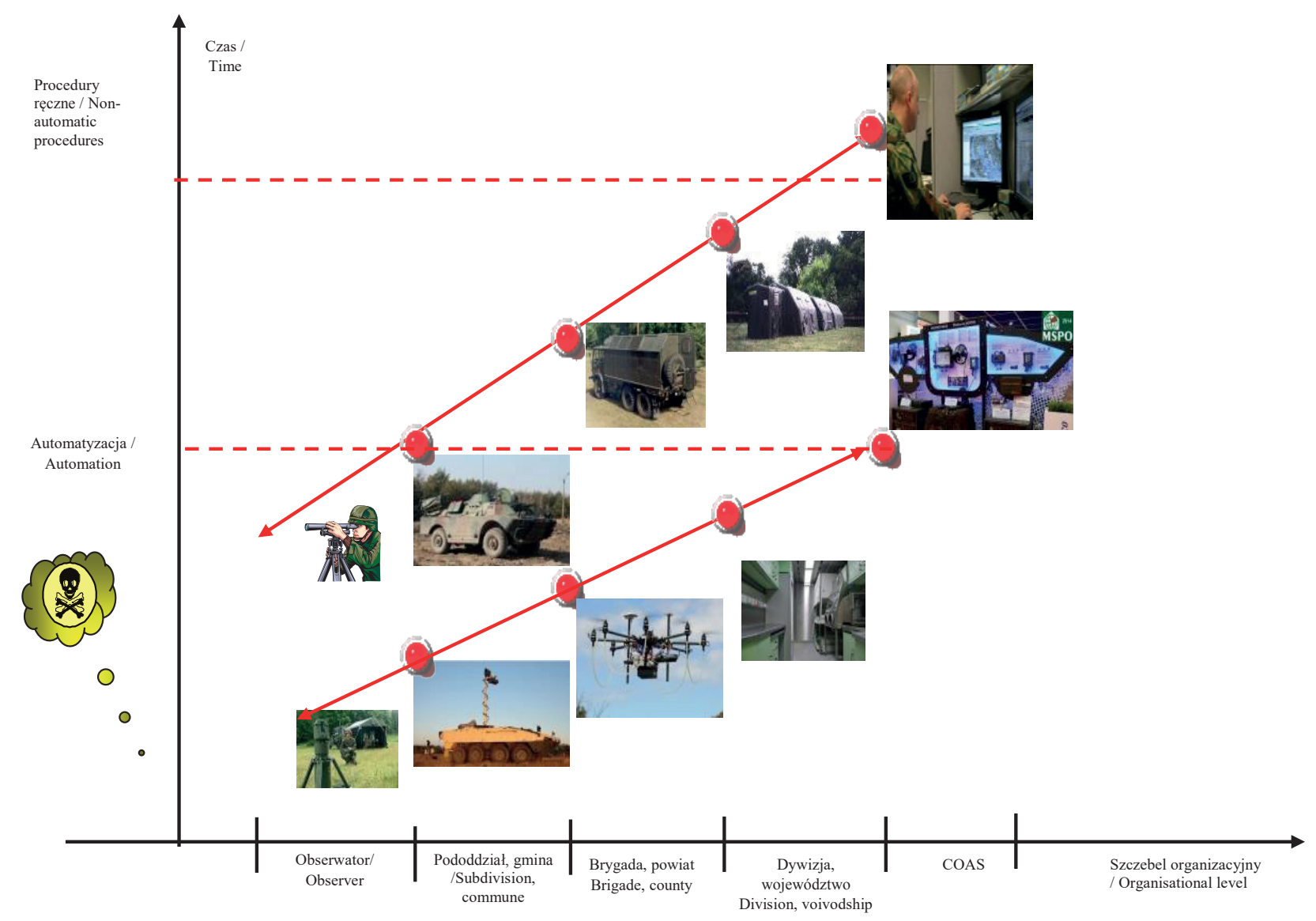

Rycina 6. Graficzna wizualizacja czasu uzyskania informacji z systemu [17]

Figure 6. Graphic visualisation of the time of information acquisition from the system [17]

W armii amerykańskiej powietrzne rozpoznanie skażeń promieniotwórczych prowadzi się za pomocą śmigłowców m.in. OH-6A (ryc. 7a) lub UH-60M Black Hawk (ryc. 7b). Pojedynczy śmigłowiec w zależności od zadanej szczegółowości rozpoznania może w ciągu godziny rozpoznać pod względem skażeń promieniotwórczych strefę o powierzchni $130-450$ km². Załoga śmigłowca składa się z pilota oraz obserwatora lub obserwatorów (zależnie od wymagań prowadzonej operacji). Na obserwatorów wyznacza się m.in. żołnierzy z pododdziałów wojsk chemicznych, żołnierzy innych rodzajów wojsk, którzy zostali w tym celu przeszkoleni, oraz żołnierzy mających doświadczenie i wykonujących regularnie loty rozpoznawcze. Podstawą planowania powietrznego rozpoznania jest naniesienie na mapę rozpoznawanego obszaru charakterystycznych punktów terenowych, które będą mogły być łatwo zidentyfikowane przez załogę podczas lotu śmigłowca. 
a)

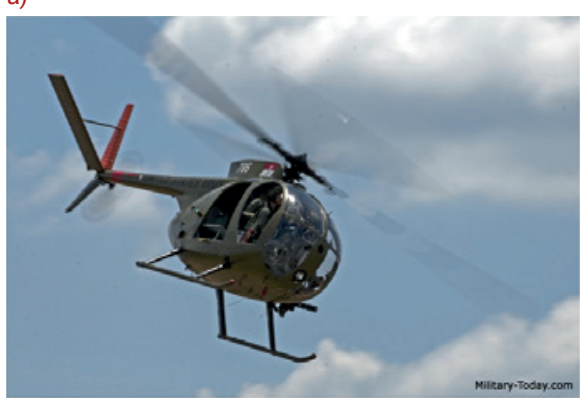

b)

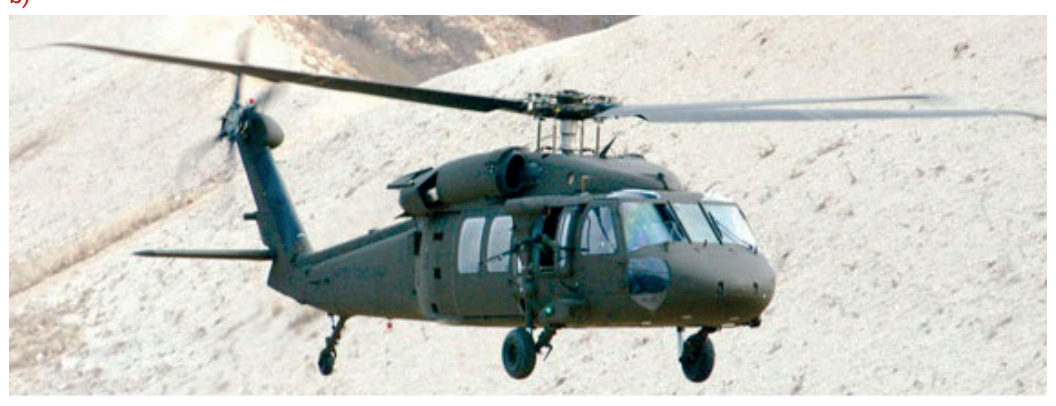

Rycina 7. Śmigłowce wykorzystywane w armii USA podczas rozpoznania skażeń:

a) OH-6A, b) UH-60M Black Hawk [18]

Figure 7. Helicopters used in US Army for contamination detection:

a) $\mathrm{OH}-6 \mathrm{~A}, \mathrm{~b}) \mathrm{UH}-60 \mathrm{M}$ Black Hawk [18]

\section{Bezzałogowe statki powietrzne}

Początek XXI wieku to implementowanie w bezzałogowych statkach powietrznych coraz to nowszych technologii związanych z miniaturyzacją, ulepszaniem systemów komputerowych, informatycznych oraz z lepszym odbiorem sygnału GPS. W BSP wyposażają się praktycznie wszystkie armie na świecie, w tym SZ RP, które od 2005 mają bezzałogowy system powietrzny Orbiter firmy Aeronautics Defense Systems (ryc. 8). Jest on tworzony przez kilka sztuk mini-BSP, wyrzutnie oraz środki sterowania. W kolejnych latach (2007-2008 oraz 2013) SZ RP zakupiły w sumie dodatkowo 20 systemów opartych na mini-BSP (Orbiter oraz - polskiej produkcji - FlyFly firmy WB Electronics). Wykorzystywano je podczas misji w Iraku i Afganistanie. W obu przypadkach zadania rozpoznawcze na rzecz polskiego kontyngentu wykonywały także amerykańskie BSP RQ-1 Predator.

XXI wiek to także gwałtowny wzrost liczby posiadanych BSP. Przykładem są m.in. wojska lądowe USA, które po atakach z 11 września 2001 r. w ciągu dziesięciu lat zwiększyły liczbę bezzałogowych statków powietrznych z 30 do 2000 [19]. Oprócz zastosowań militarnych bezzałogowe systemy powietrzne zaczęły mieć duże zastosowanie w środowiskach cywilnych (m.in. w badaniach naukowych, zarządzaniu kryzysowym i zapobieganiu katastrofom, w ochronie infrastruktury krytycznej i środowiska).

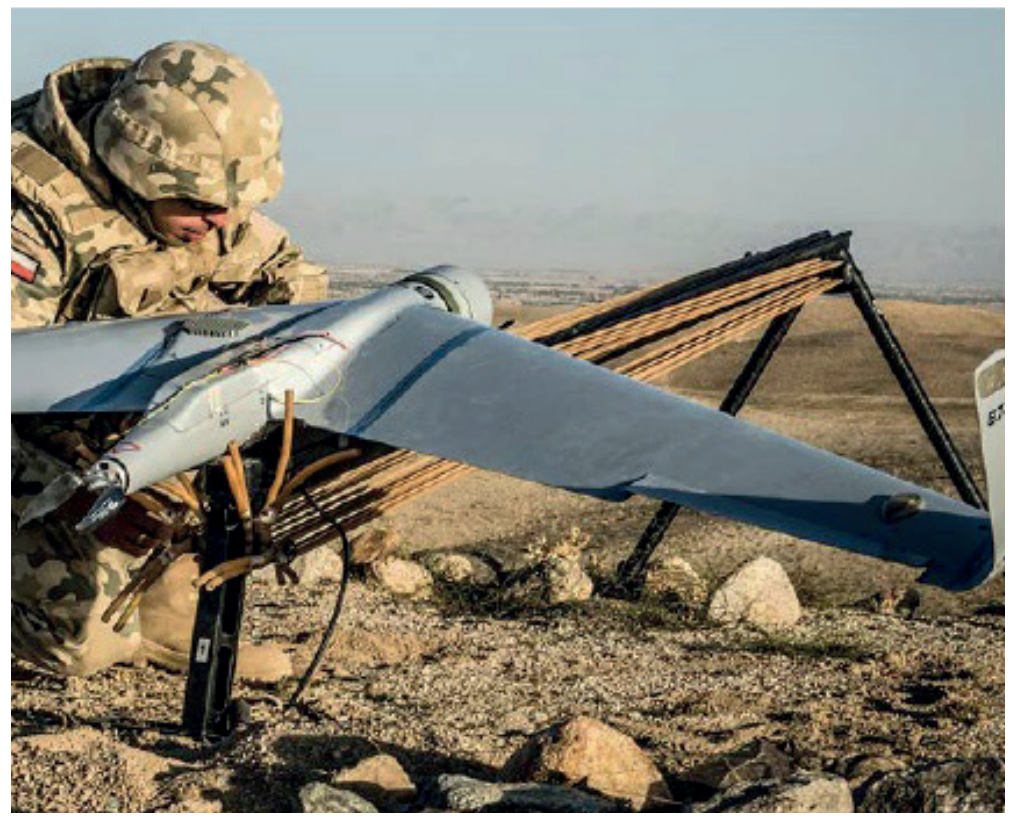

Rycina 8. Bezzałogowy statek powietrzny mini-BSP Orbiter wykorzystywany w SZ RP [20]

Figure 8. Unmanned Aerial Vehicle Mini-BSP Orbiter used in Polish Armed Forces [20]

Zróżnicowane możliwości taktyczno-techniczne nowych oraz starych bezzałogowych systemów powietrznych sprawiają, że systemy te mogą by klasyfikowane według wielu kryteriów.
W tym celu bardzo często bierze się pod uwagę takie parametry, jak: wysokość lotu, wysokość operowania, długotrwałość lotu oraz maksymalna masa startowa. 
Jedną z bardzo często wykorzystywanych klasyfikacji jest ta obowiązująca w NATO, zgodnie z którą bezzałogowe systemy powietrzne w kontekście prowadzenia wspólnych operacji przez kraje członkowskie dzielą się na 3 klasy różniące się masami startowymi:

- Klasa I obejmuje BSP o masie poniżej 150 kg, które nie wymagają tworzenia standardów certyfikacji w sojuszu. Większość z nich stanowią BSP "wyrzucane z ręki” (hand-launched), które zalicza się do kategorii: mikro, mini lub małe. Są one wykorzystywane głównie przez niewielkie pododdziały do bliskiego rozpoznania (w tym do ochrony baz) i z reguły wyposażone w detektory optoelektroniczne i detektory podczerwieni. Charakteryzują się małymi wymaganiami logistycznymi, niskimi wysokościami operowania (< $1600 \mathrm{~m}$ ), a także ograniczonym zasięgiem i długotrwałością lotów.

- Klasa Il skupia taktyczne BSP (TUAV) średniej wielkości (o masie startowej 150-600 kg). Te BSP często startują z katapulty, przy czym mogą wykonywać zadania z nieprzygotowanych logistycznie lądowisk. Przeznaczone są do wspierania działań brygady oraz niższych szczebli taktycznych w zakresie rozpoznania, monitoringu oraz identyfikacji i wskazywania celów. Dlatego wyposażone są $\mathrm{w}$ detektory optoelektroniczne, detektory podczerwieni oraz dalmierze laserowe. Podobnie jak bezzałogowce klasy I nie wymagają dużego zabezpieczenia logistycznego. Prowadzą misję na wysokości do $3000 \mathrm{~m}$.

- Klasa III obejmuje BSP o największej masie startowej (> $600 \mathrm{~kg})$, zasięgach i czasach operowania w powietrzu. Zalicza się je do 3 kategorii: MALE (Medium Altitiude Long Endurance), HALE (High Altitiude Long Endurance) oraz uderzeniowych (bojowych) bezzałogowych statków powietrznych. Aby mogły być one wykorzystywane $\mathrm{w}$ działaniach, $\mathrm{z}$ reguły wymagają odpowiednio przygotowanych lotnisk (lądowisk), a także odpowiedniego zabezpieczenia logistycznego. Wyposaża się je w najnowocześniejsze systemy nawigacji i rozpoznania (w tym radary, lasery i kamery o wysokiej rozdzielczości), a także w uzbrojenie (w tym przeciwpancerne).

Najważniejszymi kryteriami obowiązującego podziału są promień działania i typowa (operacyjna) wysokość lotu. W poszczególnych klasach wyodrębniono ponadto dodatkowe kategorie BSP, które odpowiadają poszczególnym szczeblom dowodzenia.

Tabela 1. Klasy BSP [21]

Table 1. BSP classes [21]

\begin{tabular}{|c|c|c|c|c|}
\hline $\begin{array}{l}\text { Klasa/ } \\
\text { Class }\end{array}$ & Kategoria/Category & Szczebel dowodzenia/Echelon & $\begin{array}{l}\text { Promień działania/ } \\
\text { Radius of action [km] }\end{array}$ & $\begin{array}{l}\text { Pułap operacyjny/ } \\
\text { Service ceiling [m] }\end{array}$ \\
\hline I & mikro (do $2 \mathrm{~kg}$ )/micro & drużyna, pluton/team, platoon & 5 & 61 \\
\hline I & $\operatorname{mini}(2-20 \mathrm{~kg})$ & kompania/company & 25 & 304 \\
\hline I & małe/small $(20-150 \mathrm{~kg})$ & batalion/battalion & 50 & 366 \\
\hline II & tactical & brygada/brigade & 200 & 914 \\
\hline III & Medium Altitude Long Endurance & operacyjny/operational & $\begin{array}{c}\text { nieograniczony (retranslacja)/ } \\
\text { unlimited (retranslation) }\end{array}$ & 12192 \\
\hline III & stike & operacyjny/operational & $\begin{array}{c}\text { nieograniczony (retranslacja)/ } \\
\text { unlimited (retranslation) }\end{array}$ & 19812 \\
\hline III & High Altitude Long Endurance & strategiczny/strategic & $\begin{array}{c}\text { nieograniczony (retranslacja)/ } \\
\text { unlimited (retranslation) }\end{array}$ & 19812 \\
\hline
\end{tabular}

W przypadku niestandardowych parametrów BSP, np. płatowca o masie $20 \mathrm{~kg}$ i pułapie ponad $2000 \mathrm{~m}$ lub promieniu działania ponad $200 \mathrm{~km}$, rozstrzygającym kryterium jest masa w locie. Dla podanego przykładu BSP będzie umieszczony w klasie I - do $150 \mathrm{~kg}$.

\section{Koncepcja rozwiązań technicznych [22]}

W skład opracowywanego systemu będzie wchodził pojedynczy BSP należący do kategorii mini (mini-BSP), który będzie mógł wykonywać start i lądowanie pionowe w dowolnym miejscu. W dalszej fazie rozwijania projektu przewiduje się możliwość zwiększenia liczby BSP w danym systemie lub ich połączenia w jeden większy. Podczas wyboru odpowiedniego mini-BSP za parametry krytyczne uznano te, które pozwalają na wykorzystanie go na polu walki, a którymi są m.in.: pułap lotu, prędkość podczas przelotu i rozpoznania, długotrwałość lotu oraz promień działania. Mini-BSP będzie zbudowany z materiałów odpornych na warunki atmosferyczne i uszkodzenia mechaniczne. Będzie ponadto mógł być poddawany procesom likwidacji skażeń (bez negatywnych skutków dla jego elementów) przy wykorzystaniu obecnie dostępnych metod i środków, które będą wchodziły w skład systemu.

Zakłada się, że projekt będzie stale rozwijany poprzez wyposażanie go w coraz to nowsze, doskonalsze systemy mające zwiększyć jego efektywność podczas realizacji zadań. Doświadczenia zdobyte podczas jego użytkowania w czasie testów i szkoleń, a następnie podczas działań bojowych będą systematycznie analizowane. Celem tych analiz będzie rozwijanie nowych technologii w dziedzinie robotyzacji pola walki. Jednym z krytycznych elementów zapewniających powodzenie opracowywanej koncepcji systemu powietrznego rozpoznania skażeń będzie wykonanie projektu bezzałogowego statku powietrznego spełniającego wiele specyficznych wymagań i wyposażenie tego statku w odpowiedni system detekcji skażeń. Przewiduje się wykonanie konstrukcji mini-BSP, które podda się testom wytrzymałościowym oraz odpornościowym (w tym na 
dekontaminację i narażenia elektromagnetyczne), co umożliwi wybranie wersji najbardziej optymalnej, zdolnej do prowadzenia rozpoznania i monitoringu skażeń w niesprzyjających warunkach pola walki. Podczas opracowywania konstrukcji mini-BSP powinno się zadbać o:

- maksymalne zmniejszenie jego masy przy zachowaniu wymagań dotyczących długotrwałości lotu, promienia działania oraz przenoszonego wyposażenia pokładowego (podstawowego i specjalnego);

- prostotę jego użytkowania (w tym łatwość startu, lotu i lądowania) oraz o możliwość sterowania manualnego i automatycznego (po wcześniej zaprogramowanej trasie);

- dużą odporność na wykrycie przez przeciwnika;

- niskie koszty eksploatacji.

\section{Elementy systemu [22]}

Obecnie funkcjonujący obraz bezzałogowego statku powietrznego jest często ograniczany do samolotu sterowanego za pomocą odpowiednich systemów skomunikowanych z operatorem znajdującym się na ziemi. W rzeczywistości jest to element bezzałogowego systemu powietrznego, który jest bardziej skomplikowany, niż się przypuszcza. Projektowanie tego systemu od samego początku musi uwzględniać wszystkie elementy wchodzące w jego skład. Rozważany system powietrznego rozpoznania skażeń będzie się składał z mini-BSP mającego wyposażenie podstawowe: system nawigacji, kamerę cyfrową HD, kamerę termowizyjną, oraz wyposażenie specjalne: system pobierania próbek, system detekcji oraz monitoringu skażeń, system pomiarów warunków meteorologicznych (ryc. 9). Mini-BSP za pomocą bezprzewodowej łączności radiowej będzie komunikował się ze stacją kontroli i sterowania, która wraz z systemem likwidacji skażeń będzie wchodzić w skład obsługi naziemnej mini-BSP. Wszystkie elementy systemu powietrznego rozpoznania skażeń, dzięki minimalnej masie i wielkości, będą mogły być transportowane przez dwóch żołnierzy.

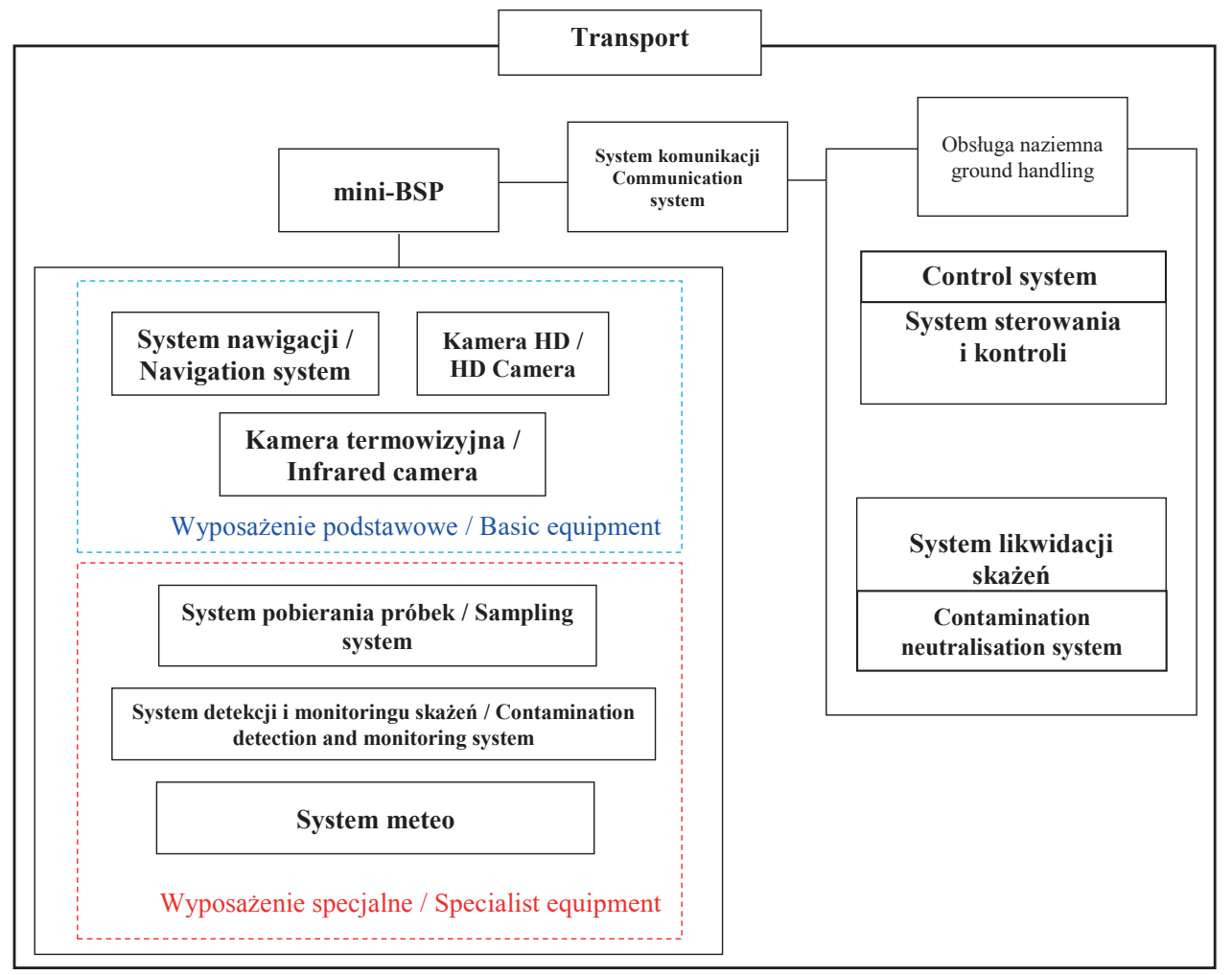

Rycina 9. Skład systemu powietrznego rozpoznania skażeń

Figure 9. The composition of the aerial system for contamination detection

Źródło: Opracowanie własne.

Source: Own elaboration.

\section{Bezzałogowy statek powietrzny}

Głównym zadaniem mini-BSP będzie przemieszczenie detektorów oraz systemów (będących elementem wyposażenia podstawowego oraz specjalnego) umożliwiających funkcjonowanie omawianego systemu powietrznego rozpoznania skażeń w miejsce prowadzenia misji - rejon skażony. W skład mini-BSP będą wchodzić: system komunikacji (łączności), system stabilizujący lot, system kontroli, źródło zasilania oraz elementy umożliwiające start, lot i późniejsze odzyskiwanie mini-BSP. Mini-BSP będzie miał napęd elektryczny zasilany np. bateriami litowo-jonowymi umożliwiającymi godzinne patrolowanie oraz półtoragodzinny lot (50 km tam i z powrotem) bez konieczności ich ładowania. Mini-BSP będzie charakteryzował się także dużą manewrowością, w tym możliwością prowadzenia 
rozpoznania, monitoringu skażeń oraz pomiaru warunków meteorologicznych tuż nad powierzchnią ziemi, nawet w trudnych warunkach terenowych. W tym celu zastosowana konstrukcja mini-BSP będzie pozwalać na wykonywanie pionowego startu i lądowania, a także zawisu w powietrzu w celu pobrania próbek lub prowadzenia monitoringu skażeń w danym punkcie. Maksymalna prędkość mini-BSP podczas obserwacji i przelotu wyniesie $20-40 \mathrm{~m} / \mathrm{s}$. Lot będzie odbywał się po trajektorii
Lo-Hi-Lo (nisko - wysoko -nisko). Pułap lotu wysokiego będzie znajdował się poza zasięgiem skutecznym broni strzeleckiej (500-600 m), a pułap lotu niskiego - uzależniony od rodzaju misji - będzie mógł znajdować się nawet tuż nad powierzchnią ziemi. Masa całkowita mini-BSP nie przekroczy $15 \mathrm{~kg}$, przy czym masa przenoszonego wyposażenia wyniesie około $30 \%$ jej wartości (przykładowe rozwiązania techniczne przedstawiono na ryc. 10 i 11).

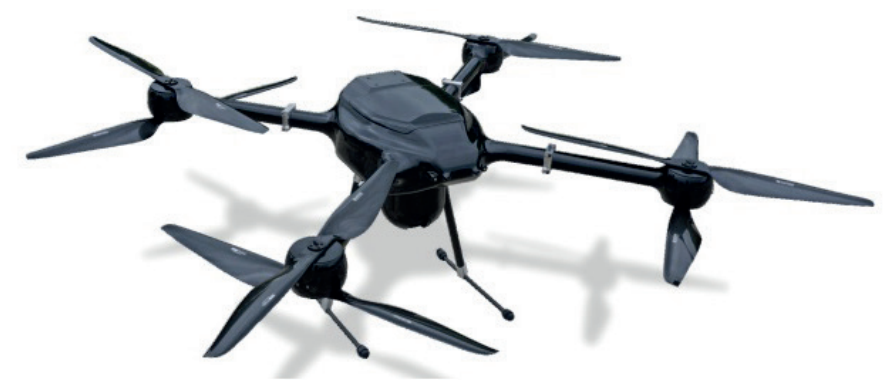

Rycina 10. Bezzałogowy statek powietrzny (mini-BSP) Atrax

(masa startowa: 7-22 kg; udźwig: 15 kg; promień działania: 5 km; loty prostoliniowe: <35 km; pułap lotu: <1000 m; długotrwałość lotu: 45-60 min) [23]

Figure 10. Unmanned Aerial Vehicle (mini-UAV) Atrax

(starting mass: 7-22 kg; maximum load: $15 \mathrm{~kg}$; range radius: $5 \mathrm{~km}$; straight flights: $<35 \mathrm{~km}$; maximum altitude: $<1000 \mathrm{~m}$; flight time: $45-60 \mathrm{~min}$ ) [23]

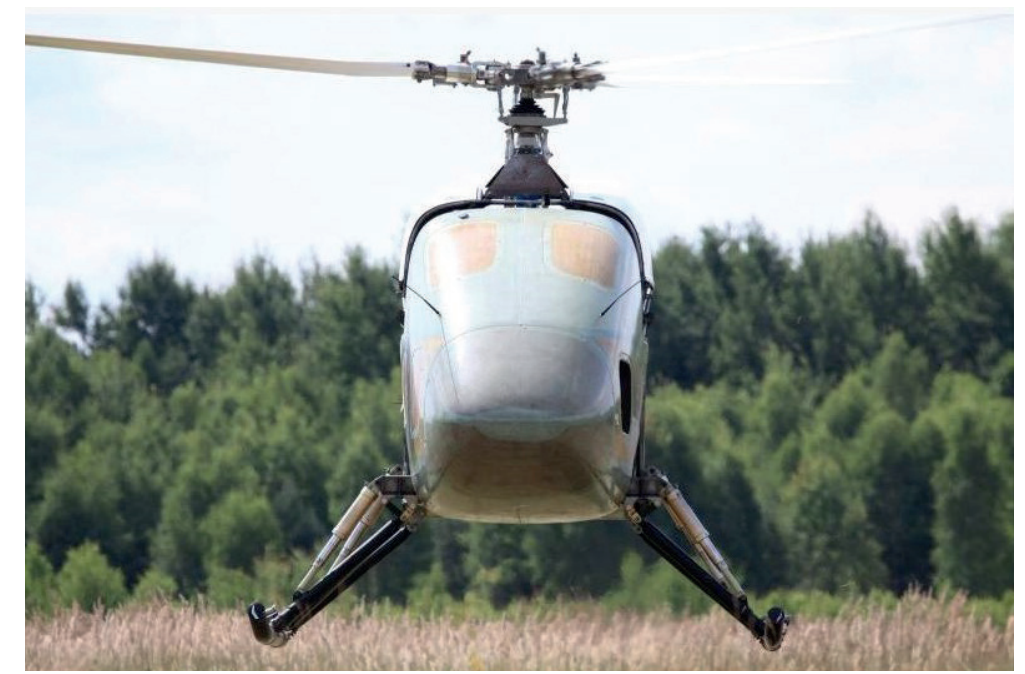

Rycina 11. Bezzałogowy statek powietrzny ILX-27

(masa startowa: 1100 kg; udźwig: 300 kg; prędkość maksymalna: 215 km/h; pułap lotu: 4000 m; zasięg lotu: 450 km) [24]

Figure 11. Unmanned Aerial Vehicle ILX-27

(starting mass: 1100 kg; maximum load: 300 kg; maximum speed: 215 km/h; maximum altitude: 4000 m; range: 450 km) [24]

\section{Obsługa naziemna}

Obsługa naziemna będzie tworzona przez stację sterowania i kontroli oraz system likwidacji skażeń. W skład stacji będą wchodzić: laptop z monitorem, manipulator, zestaw antenowy oraz akumulatory. Jeśli chodzi o system likwidacji skażeń, to ze względu na to, że zgodnie z proponowaną koncepcją będzie on odkrytym układem elektroniczno-mechanicznym (z elementami optoelektronicznymi), metody "mokre" stosowane w SZ RP staną się nieprzydatne. Koncepcyjnie system likwidacji skażeń będzie oparty na komorze (np. w postaci namiotu) oraz układzie do generowania czynników aktywnych. System może bazować na metodzie likwidacji skażeń przy wykorzystaniu gazowego (waporyzowanego) nadtleneku wodoru (GNW). Wstępne badania wskazują na dużą kompatybilność GNW z materiałami konstrukcyjnymi, powłokami lakierniczymi, układami i aparaturą elektroniczną [25]. 
Wyposażenie podstawowe

W początkowej fazie rozwijania projektu mini-BSP będzie miał dwie kamery wyposażone w systemy stabilizacji obrazu - telewizyjną HD (o wysokiej rozdzielczości nagrywanych filmów) oraz termowizyjną. Kamery umożliwią prowadzenie obserwacji w jak największym polu widzenia oraz sterowanie mini-BSP zarówno w dzień, jak i w nocy. Oprócz kamer mini-BSP będzie zawierał system nawigacji, który pozwoli na określenie jego położenia w dowolnym czasie, a tym samym na sterowanie

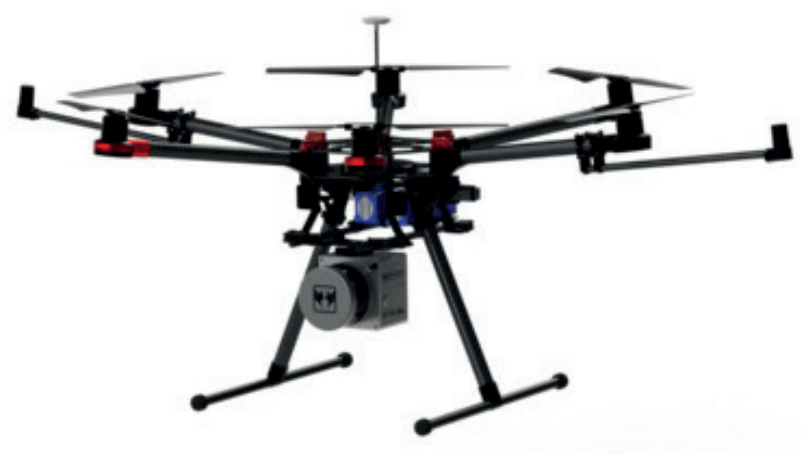

lotem oraz wykonanie samodzielnego lotu do zaprogramowanego miejsca w przypadku utraty łączności z naziemną stacją kontroli i sterowania. W kolejnych fazach rozwijania projektu mini-BSP powinno się wyposażyć także w: kamery wielospektralne, dalmierz laserowy (do wskazywania celów) oraz niewielki LiDAR umożliwiający zobrazowanie terenu wokół mini-BSP w promieniu kilkudziesięciu metrów (ryc. 12). Nowe detektory i wyposażenie mini-BSP będą dobierane lub projektowane tak, żeby nie została przekroczona jego dopuszczalna masa.

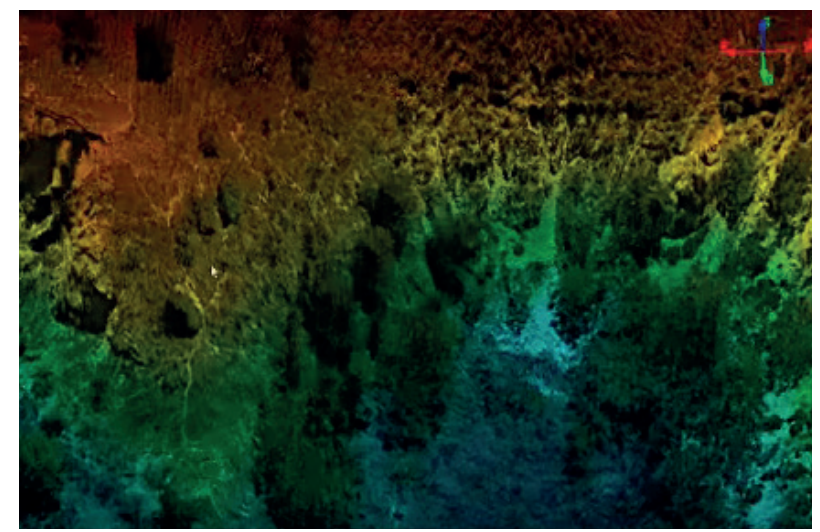

Rycina 12. Phoenix Aerial AL3-16 Velodyne VLP-16 RTK UAV LiDAR system

(parametry lidaru: masa - 1,8 kg; zasięg - $120 \mathrm{~m}$; do 6 tys. pomiarów/s w polu widzenia do $30^{\circ} \mathrm{w}$ pionie i $240^{\circ} \mathrm{w}$ poziomie;

zobrazowanie fotogrametryczne wielospektralne oraz termalne) [26]

Figure 12. Phoenix Aerial AL3-16 Velodyne VLP-16 RTK UAV LiDAR system

(lidar parameters: mass $-1,8 \mathrm{~kg}$; range $-120 \mathrm{~m}$; up to 6 thous. measurements/s in the view area up to $30^{\circ}$ vertically and $240^{\circ}$ horizontally; photogrametric multi-spectral and thermal display [26]

Wyposażenie specjalne (ryc. 13)

Wykonywanie zadań specjalistycznych w ramach opracowywanej koncepcji będzie oparte na czterech systemach: monitoringu i detekcji skażeń, pomiaru parametrów meteorologicznych, pobierania próbek gazowych oraz integracji zbieranych danych.

- System monitoringu i detekcji skażeń będzie się składał z: detektora skażeń chemicznych, detektora TSC i detektora skażeń promieniotwórczych. Mają to być układy (elektroniczne, optoelektroniczne) gwarantujące szybkie wykrycie, identyfikację (z założonym prawdopodobieństwem) oraz określenie stężenia substancji niebezpiecznej lub mocy dawki promieniowania. Powinny być one sterowane i kontrolowane przez system pokładowy oraz połączone z układem czerpni do pobierania próbek skażonego powietrza. Układ czerpni ma się składać z układu sterowania (np. do podgrzania układu dolotowego); automatycznie wysuwanej, teleskopowej rurki o długości $50 \mathrm{~cm}$ oraz układu wytwarzającego podciśnienie. Zastosowany układ detektorów będzie pozwalał także na monitorowanie skażeń w danym obszarze.

- System pomiaru parametrów meteorologicznych umożliwi dostarczanie w czasie rzeczywistym danych na temat: temperatury powietrza (na zadanych wysokościach), prędkości i kierunku wiatru oraz wilgotności względnej powietrza. Część czujników wchodzących w skład systemu zostanie umieszczona na przystawce do pobierania próbek.

- System pobierania próbek gazowych będzie pobierał i gromadził określonej objętości trzy różne próbki gazowe zassane z czerpni do hermetycznych pojemników. Zgromadzone próbki będzie można poddać dokładnej analizie w specjalistycznych laboratoriach stacjonarnych. W dalszej fazie rozwijania systemu powinno się zwiększyć możliwości systemu pobierania próbek, uzupełniając go o pobieranie próbek gleby i wody.

- Integrator z komputerem z oprogramowaniem umożliwi zautomatyzowaną integrację zbieranych danych ze specjalistycznego sprzętu pomiarowego, tworzenie meldunków i ich transmisję droga radiową.

Wszystkie systemy wchodzące w skład wyposażenia specjalnego, podobnie jak te wchodzące w skład wyposażenia podstawowego, będą dobierane i rozwijane tak, żeby były proste w obsłudze i nie spowodowały przekroczenia dopuszczanej masy całkowitej mini-BSP. 


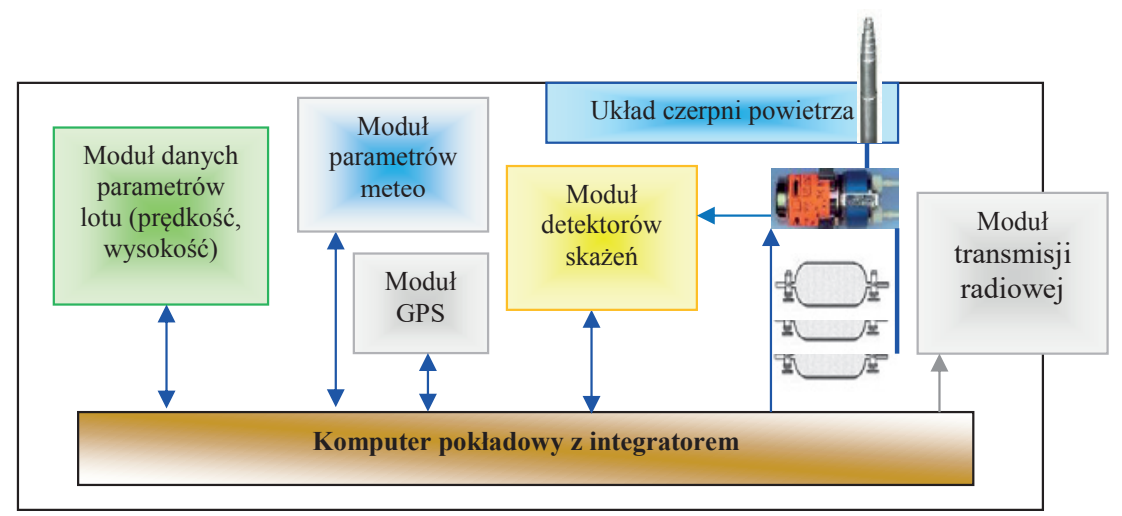

Rycina 13. Schemat blokowy wyposażenia mini-BSP dla systemu powietrznego rozpoznania skażeń Źródło: Opracowanie własne.

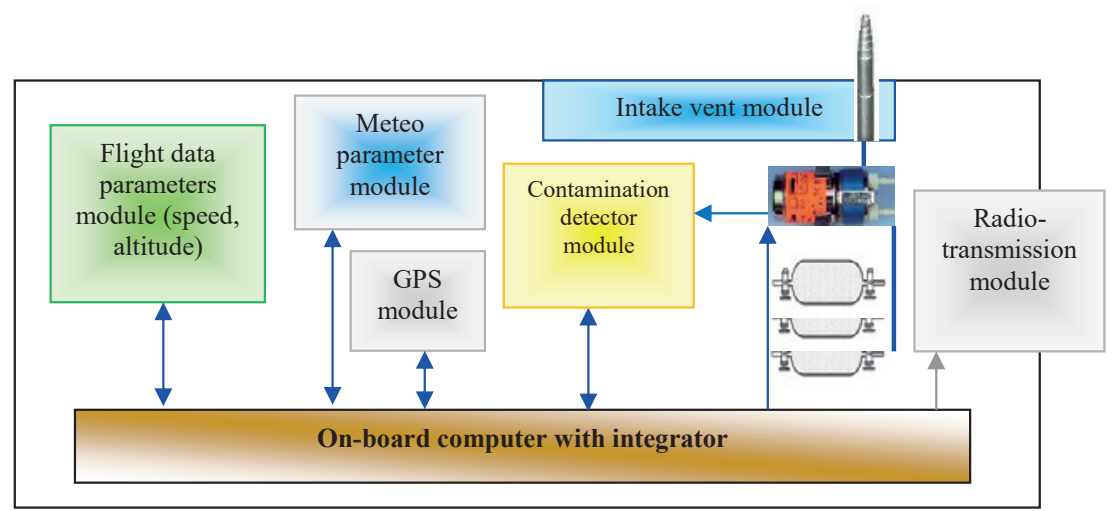

Figure 13. Block scheme of the mini-UAV equipment for the aerial contamination detection system Source: Own elaboration.

\section{Sposób użycia oraz przeznaczenie systemu}

Pokładowy, centralny system kontroli i sterowania mini-BSP będzie komunikował się z operatorem obsługującym stację naziemną za pośrednictwem systemu łączności radiowej w promieniu około $25 \mathrm{~km}$. Operator, wykorzystując odpowiedni interfejs, będzie mógł ustalać jeden w dwóch trybów pracy bezzałogowego systemu - automatyczny lub manualny. W trybie automatycznym przed rozpoczęciem wykony wania zadania będzie musiał z góry określić parametry lotu (profil, prędkość i trasę przemieszczania się mini-BSP oraz miejsce wylądowania w przypadku utraty łączności), a także sposób i parametry pracy przenoszonych urządzeń i systemów specjalnych w czasie rozpoznania i monitoringu skażeń. Operator będzie miał możliwość szybkiej i łatwej zmiany parametrów pracy nawet w trakcie wykonywania wcześniej zaprogramowanego zadania, w tym całkowitej jego zmiany na nowe. Wraz z dalszym rozwojem i wdrażaniem rozważanego systemu zakłada się ulepszanie jego układów automatycznej kontroli i sterowania, dzięki czemu będzie on mógł coraz bardziej autonomicznie wykonywać zadania przy coraz mniejszej ingerencji człowieka. Zakłada się jednak, że na początkowym etapie użytkowania systemu wykorzystywany będzie głównie tryb manualny. W wersji wyjściowej trasa przelotu oraz pozycjonowanie mini-BSP na podstawie danych z GPS za pomocą odpowiedniego interfejsu oraz na podstawie informacji uzyskanych z detektorów i systemów przenoszonych przez mini-BSP operator będzie mógł w czasie rzeczywistym ustalać trasę oraz parametry lotu oraz parametry pracy urządzeń pokładowych. Rozważa się także wprowadzenie trybu półautomatycznego, w którym lot mini-BSP będzie odbywał się automatycznie po zaplanowanej trasie, a praca urządzeń pokładowych będzie sterowana manualnie.

Operator mini-BSP zostanie wyposażony w przenośny, spełniający wojskowe wymagania komputer z wgraną cyfrową mapę terenu i wyświetlającymi się informacjami niezbędnymi do tego, by kontrolować lot mini-BSP i działanie urządzeń pokładowych oraz by nimi sterować. Podstawowymi danymi dostępnymi na ekranie laptopa będą:

- mapa terenu;

- pozycja mini-BSP w danej chwili;

- trasa przelotu mini-BSP;

- obraz z kamery dziennej/nocnej przekazywany online;

- zaznaczone punkty do szczegółowego rozpoznania przez mini-BSP;

- informacje o stanie mini-BSP (np. stan naładowania baterii, prędkość, wysokość lotu);

- informacje z systemu detekcji i monitoringu skażeń o aktualnym trybie pracy, stanie oraz bieżących wynikach pomiarów;

- informacje z systemu pomiaru parametrów meteorologicznych; 
- wykryte rejony skażeń oraz ich współrzędne wraz z określonym rodzajem i określoną wartością stężenia (mocą dawki);

- położenia innych obiektów w rejonie misji prowadzonej przez mini-BSP.

- inne dane o terenie, takie jak: przeszkody terenowe, warstwice, odległość mini-BSP od punktów kontrolnych.

W początkowej fazie rozwoju i implementacji rozważany projekt będzie jednak głównie dostosowywany i rozwijany pod względem wymagań i potrzeb SZ RP oraz jednostek reagowania kryzysowego. Zakłada się, że drużyny rozpoznania skażeń zostaną wyposażone w pojedyncze systemy powietrznego rozpoznania skażeń uzupełniające działanie drużyn w zakresie m.in.:
- prowadzenia obserwacji;

- wykrywania, identyfikacji i monitoringu skażeń;

- wyznaczania dróg obejścia rejonów skażonych i dróg przejścia przez te rejony;

- pomiaru parametrów meteorologicznych w przyziemnej warstwie atmosfery;

- pobierania skażonych próbek (praktyczne rozwiązanie ilustruje ryc. 14).

Przyjmuje się też, że w dalszej fazie realizacji projektu sprzęt i urządzenia dotychczas wykorzystywane przez drużyny rozpoznania skażeń (pojazdy rozpoznania skażeń wraz z wyposażeniem) zostaną całkowicie zastąpione bezzałogowymi systemami powietrznego rozpoznania skażeń.

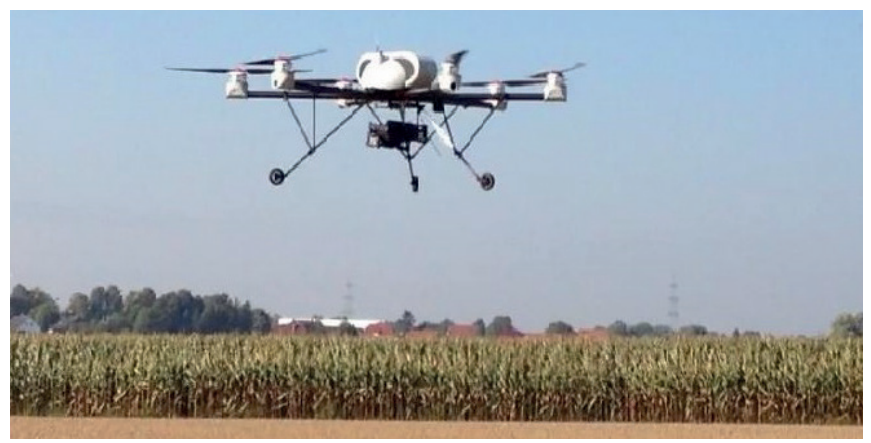

Rycina 14. Dron z detektorem skażeń

(powierzchnia obszaru obserwacji: $450 \mathrm{~km}^{2}$; czas pełnego skanowania: regulowany od $10 \mathrm{~s}$; generowanie sygnału o skażeniach: w czasie rzeczywistym; generowanie współrzędnych obłoku: w czasie rzeczywistym; kąty pomiaru: w poziomie $-360^{\circ}, \mathrm{w}$ pionie $-30^{\circ}+90^{\circ} ;$ prędkość kątowa skanowania: regulowana; błąd pomiaru [odległości i głębokości obłoku]: \pm 2 m; obsługa: 1 osoba) [17]

Figure 14. Drone with contamination detector

(observation area: $450 \mathrm{~km}^{2}$; full scanning time - adjusted from $10 \mathrm{~s}$, generation of contamination signal: real time; generation of cloud coordinates: real time; measurement angles: horizontally $-360^{\circ}$; vertically $-30^{\circ}+90^{\circ}$; angular scanning speed: adjusted; measurement error [distance and cloud depth]: $\pm 2 \mathrm{~m}$; service: 1 person) [17]

Na ryc. 15 przedstawiono (w sposób poglądowy) korzyści, jakie w zakresie bezpieczeństwa wynikają z wykorzystania statków bezzałogowych w systemie rozpoznania skażeń, na ryc. 16
- sposób prowadzenia rozpoznania skażeń stref przez środki powietrzne, a na ryc. 17 - praktyczne wykorzystanie "dronów” do wykrywania zanieczyszczeń powietrza w miastach.

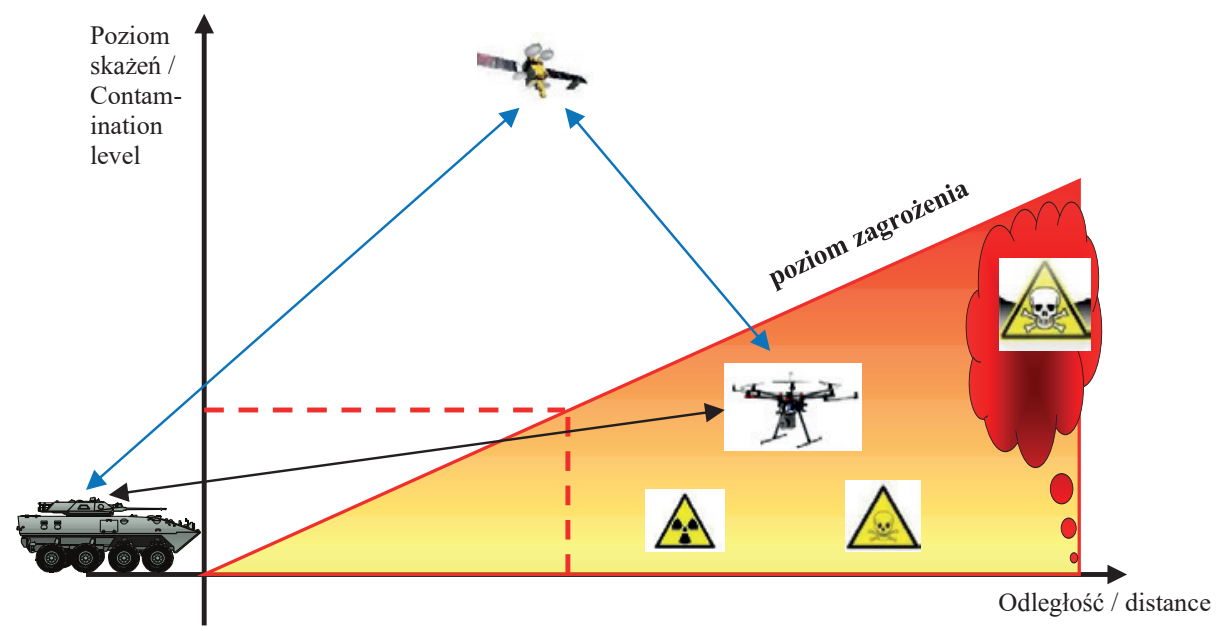

Rycina 15. Możliwości systemu według koncepcji: rozpoznać, nie wchodząc w rejon skażony

Figure 15. System capacity according to the concept: to detect without entering the contaminated area

Źródło: Opracowanie własne.

Source: Own elaboration. 

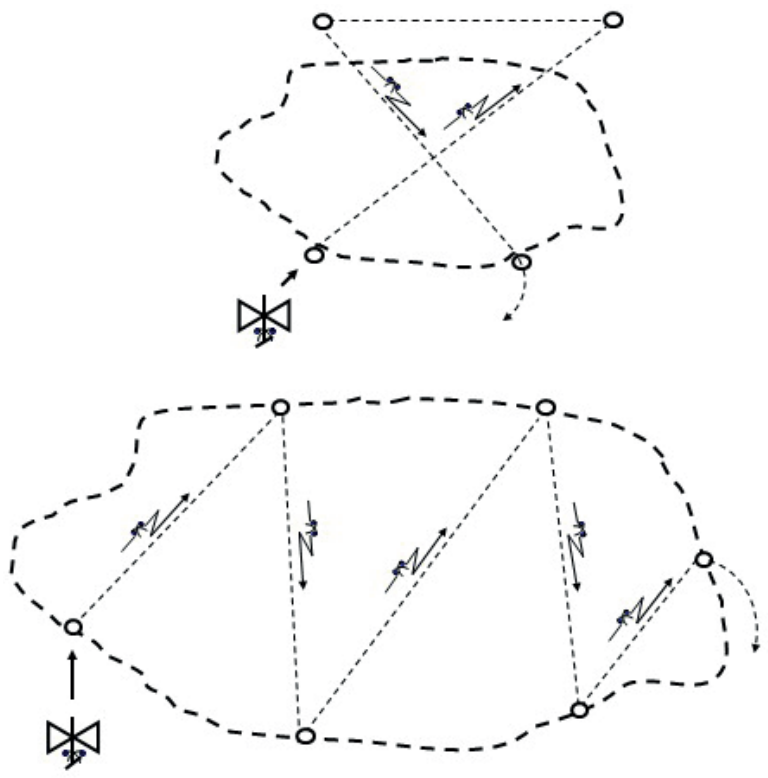

Rycina 16. Powietrzne rozpoznania skażeń: a) małych stref, b) dużych stref [27]

Figure 16. Aerial contamination detection: a) small zones, b) large zones [27]

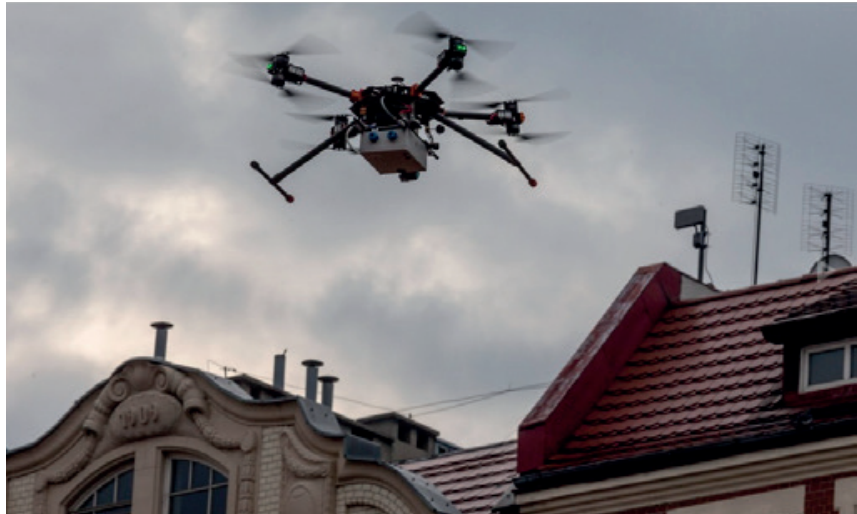

Rycina 17. Testy naukowców z Akademii Górniczo-Hutniczej z wykorzystaniem dronów do monitoringu emisji szkodliwych substancji z lokalnych palenisk nad bytomskim rynkiem [28]

Figure 17. Tests made by scientists from AGH University of Technology using drones for the monitoring of the emission of harmful substances from local furnaces over the Bytom Market Square [28]

\section{Podsumowanie}

Wśród wielu współczesnych zagrożeń największy strach i obawy społeczeństwa budzą zagrożenia skażeniami. Mogą one powstać w wyniku niszczycielskich sił natury lub nieodpowiedzialnej działalności człowieka. Obie te przyczyny są ze sobą powiązane, a wzajemnie na siebie wpływając, dodatkowo utrudniają analizę zagrożeń skażeniami.

W RP za główne źródła skażeń można uznać: działania militarne, katastrofy i awarie techniczne oraz terroryzm.

Ogólnie za mało prawdopodobne uważa się to, by przeciwko RP, która jest członkiem UE i NATO, jakieś państwo wystąpiło zbrojnie z wykorzystaniem BMR. Zagrożenia tego nie można jednak całkowicie zlekceważyć, zwłaszcza że tuż obok wschodnich granic RP stacjonują znaczące siły i środki militarne (w tym
BMR). Od kilku lat obserwuje się gwałtowny wzrost zagrożenia konfliktem militarnym w Europie (na największą skalę od czasu upadku Związku Radzieckiego), który jest związany m.in. z sytuacją na Ukrainie. Niepokojąca jest także agresywna polityka Rosji oraz prowokacyjne działania militarne tego kraju wobec państw Europy Środkowo-Wschodniej. Dodatkowo niebezpieczeństwo to zwiększa brak jednomyślności w postrzeganiu obecnych zagrożeń militarnych przez państwa członkowskie NATO i UE. W pewnym momencie może dojść do regionalizacji obu sojuszy, przez co mogą one stracić wiarygodności na arenie międzynarodowej, pokazując swoją słabość potencjalnym przeciwnikom.

Oprócz konfliktów zbrojnych możliwym źródłem skażeń w Polsce są znajdujące się na jej obszarze zakłady przemysłowe wykorzystujące w swojej działalności substancje niebezpieczne. Chodzi tu o ponad 1200 zakładów przemysłowych mogących być 
źródłem poważnych awarii, z których ponad 180 należy do grupy zakładów o dużym ryzyku wystąpienia awarii przemysłowej. Substancje niebezpieczne mogą zostać uwolnione nie tylko podczas ich przetwarzania i przechowywania, ale także w trakcie ich transportu. W RP największe ilości substancji niebezpiecznych przewozi się transportem samochodowym (kilkaset milionów ton rocznie), który jest jednym z najbardziej niebezpiecznych środków transportu ze względu na brak wyznaczonych tras przewozu, zły stan techniczny pojazdów-cystern oraz nawierzchni polskich dróg. Doświadczenia z przeszłości pokazują, że źródłem skażeń na obszarze danego państwa mogą być także zakłady przemysłowe znajdujące się na terytoriach państw sąsiadujących. Chodzi tu o elektrownie jądrowe, w których może dojść do awarii, jak to było w Czarnobylu czy Fukushimie. Obecnie w promieniu $300 \mathrm{~km}$ od granic RP znajduje się 9 elektrowni atomowych, w których pracują 24 reaktory jądrowe mogące - w wyniku awarii - spowodować skażenia znacznych obszarów.

Człowiek może uwolnić substancje niebezpieczne do środowiska nieświadomie (np. w wyniku nieszczęśliwego wypadku lub niesprawności technicznej) lub świadomie (akty terroryzmu). Mimo że terytorium RP dotychczas nie było bezpośrednim celem ataku terrorystów, globalność tego zjawiska pokazała, że żadne państwo na świecie nie może czuć się w pełni bezpiecznie. Udział SZ RP w wielu misjach pokojowych i stabilizacyjnych na obszarach objętych konfliktami zbrojnymi mającymi charakter wojen religijnych wymierzonych przeciwko muzułmanom, a także bliski sojusz z USA w „wojnie z terroryzmem” powodują, że główne zagrożenie atakami występuje ze strony terrorystów islamskich. Polska uważa się za możliwy cel ich ataków odwetowych (w przypadku niepowodzeń ataków na państwa zachodnie i USA) oraz dogodne zaplecze logistyczne do ataków na inne państwa.

Aby państwa mogły efektywnie ochronić ludność przed skażeniami, muszą mieć odpowiednią ilość sił i środków, które pozwolą m.in. szybko wykryć, zidentyfikować i monitorować te skażenia oraz szybko o nich zaalarmować. Ważne jest także, żeby współpracowały ze sobą i nawzajem się uzupełniały. W RP osiągnięto to na mocy rozporządzenia Rady Ministrów z dnia 16 października 2006 roku, które powołało Krajowy System Wykrywania Skażeń i Alarmowania. Jego utworzenie pozwoliło na współpracę oraz interoperacyjność działania w ramach jednego systemu dotychczas oddzielnie funkcjonujących organów oraz jednostek układu militarnego i pozamilitarnego wydzielonych w zakresie ochrony przed skażeniami. Było to możliwe głównie dzięki ujednoliceniu ich metodyk i procedur działania, w tym m.in. dzięki zastosowaniu identycznych formatów meldunków i informacji o skażeniach oraz procedur ich przekazywania, a także jednolitego obiegu i jednolitej wymiany informacji o skażeniach. Krajowy System Wykrywania Skażeń i Alarmowania jest tworzony przez Centrum Dyspozycyjne, podsystemy funkcjonalne (do których należy m.in. System Wykrywania Skażeń SZ RP) oraz jednostki organizacyjne. Zadaniem podsystemów jest wykrywanie skażeń i alarmowanie o nich. Z kolei jednostki organizacyjne zajmują się analizą skażeń i oceną sytuacji skażeń, na podstawie czego opracowują, ogłaszają i inicjują działania interwencyjne. Wszystkie działania realizowane w ramach systemu koordynuje Minister Obrony Narodowej przy pomocy Centrum Dyspozycyjnego.
Podobnie jak w innych armiach NATO, tak i w SZ RP rozpoznanie skażeń może być prowadzone dzięki etatowym lub nieetatowym siłom i środkom naziemnego lub powietrznego rozpoznania skażeń. Etatowe pododdziały powietrznego rozpoznania skażeń SZ RP były tworzone przez załogi kluczy śmigłowców Mi-2rs „Padalec”. W wyniku wycofania śmigłowców Mi-2 z użytkowania i niewprowadzenia innych rozwiązań SZ RP nie mają możliwości prowadzenia powietrznego rozpoznania skażeń. Dodatkowo zadania w ramach powietrznego rozpoznania skażeń mogą wykonywać nieetatowe pododdziały śmigłowców innych typów oraz samoloty wyposażone w odpowiednie przyrządy pomiarowe (np. śmigłowiec transportowy Mi-8 lub W3 "Sokół”). Wykorzystując w systemie rozpoznania skażeń środki powietrzne, można znacznie ograniczyć ekspozycję załóg na skażenie (w tym na promieniowanie). Osiąga się to m.in. dzięki możliwości dużo szybszego prowadzenia rozpoznania skażeń. Środki powietrzne charakteryzują się e także dużą mobilnością i manewrowością, przez co mogą dotrzeć do miejsc niedostępnych lub trudno dostępnych dla naziemnych pododdziałów rozpoznawczych. Etatowy klucz śmigłowców rozpoznania skażeń składający się z trzech Mi-2rs w ciągu godziny mógł rozpoznać 540 km dróg, 3 rejony ześrodkowania związków taktycznych oraz 2-3 ślady obłoków promieniotwórczych. Do głównych wad powietrznego rozpoznania skażeń zalicza się ograniczone możliwości wykonywania zadań w trudnych warunkach pogodowych, a także mniejszą niż w przypadku rozpoznania naziemnego dokładność uzyskanych wyników.

W armiach NATO do naziemnego rozpoznania skażeń wykorzystuje się głównie systemy automatyczne oparte na stacjonarnych i przewoźnych lidarach, a gdy sytuacja wymaga wysłania patrolu, w miejsce ludzi jest kierowany jest samobieżny robot. Do powietrznego rozpoznania skażeń wykorzystywane są zaś pilotowe i bezpilotowe środki techniczne wyposażone w systemy detektorów, przetworników, środków łączności itp.

Należy nadmienić, że w RP znajdują się wszystkie elementy techniczne i technologiczne niezbędne do odbudowy systemu powietrznego rozpoznania skażeń.

\section{Wnioski}

1. Wykorzystanie bezzałogowych statków powietrznych w systemie powietrznego rozpoznania i identyfikacji skażeń znacznie zwiększy efektywność działania nie tylko SWS SZ RP, ale także innych podsystemów KSWSiA. BSP w znacznym zakresie wzmocnią pododdziały naziemnego rozpoznania skażeń, a w dalszej perspektywie mogą nawet je zastąpić w wykonywaniu większości zadań.

2. Do głównych zalet wykorzystania BSP w systemie powietrznego rozpoznania skażeń można zaliczyć: brak konieczności narażania personelu na skażenie oraz oddziaływanie przeciwnika, względnie mała wykrywalność BSP przez radary, minimalne efekty wizualne oraz akustyczne podczas prowadzenia rozpoznania (co zmniejsza prawdopodobieństwo wykrycia BSP przez przeciwnika), duża mobilność i manewrowość oraz możliwość prowadzenia działań w trudnych warunkach terenowych. 


\section{Literatura}

[1] Strategia bezpieczeństwa narodowego Rzeczypospolitej Polskiej, Warszawa 2014.

[2] Europejska strategia bezpieczeństwa. Bezpieczna Europa w lepszym świecie, Urząd Publikacji Unii Europejskiej, Luksemburg 2009.

[3] Czaputowicz J., System czy nieład? Bezpieczeństwo europejskie u progu XXI wieku, PWN, Warszawa 1998, 23.

[4] Informacja o wynikach kontroli „Wykonywanie zadań przez administrację publiczną w zakresie bezpieczeństwa przewozu towarów niebezpiecznych", Najwyższa Izba Kontroli, Departament Infrastruktury, Warszawa 2012.

[5] www.chemiaibiznes.com.pl/aktualnosc/rynek-transportu-substancji-chemicznych-wykazuje-istotny-potencjal-wzrostu [dostęp: 01.06.2016]

[6] Transport. Wyniki działalności w 2010 r., Główny Urząd Statystyczny, Warszawa 2011.

[7] http://www.gios.gov.pl/images/dokumenty/powazne_awarie/raport [dostęp:1.02.2017]

[8] Harmata W., Ochrona przed skażeniami. Cz. I. Współczesne zagrożenia. Podstawy teoretyczne indywidualnej ochrony przed skażeniami, Wydawnictwo WAT, Warszawa 2013

[9] https://www.darlowo.pl/pl/?page=wiadomosci\&wiadomosc $=2897$ [dostęp: 1.02.2017]

[10] Harmata W., Problemy indywidualnego odkażania umundurowania, „Biuletyn Informacyjny WIChiR” 1988, 1(15)/88.

[11] Rozporządzenie Rady Ministrów z dnia 16 października 2006 r. w sprawie systemów wykrywania skażeń i właściwości organów w tych sprawach (Dz. U. Nr 191, poz.1415).

[12] Rozporządzenie Rady Ministrów z dnia 7 stycznia 2013 r. w sprawie systemów wykrywania skażeń i powiadamiania o ich wystąpieniu oraz właściwości organów w tych sprawach (Dz. U., poz. 96).

[13] http://rcb.gov.pl/wp-content/uploads/2011/02/kswsia.pdf [dostęp: 01.06.2017]

[14] Ustawa z dnia 26 kwietnia 2007 r. o zarządzaniu kryzysowym Dz.U. 2007 nr 89 poz. 590

[15] http://lotniczapolska.pl/Mi-2-i-Mi-8-w-cwiczeniu-BLYSK-11,22080 [dostęp: 1.06.2017].

[16] Latoszewski P., Powietrzne rozpoznanie skażeń - przyszłość czy relikt?, „Przegląd Wojsk Lądowych” 2009, 1, 37-39.

[17] Witczak M., Systemy rozpoznania skażeń oparte na zaawansowanych systemach detekcyjnych i bezzałogowych platformach. Zdalna detekcja, Nałęczów 2016.

[18] www.military-today.com/helicopters/oh6_cayuse.htm; www.sikorsky.com/Pages/Products/Military/BlackHawk/UH60M.aspx [dostęp:1.05.2016].

[19] Austin R., Unmanned Aircraft Systems. UAVS Design, Development and Deployment, A Joh Wiley and Sons, Ltd., Publication, Chippenham 2010.

[20] Bączyk N., W oczekiwaniu na start, „Polska Zbrojna” 2014, 10.

[21] http://militarium.net/klasyfikacje-i-wymagania-dla-bezzalogowych-statkow-powietrznych-uav-w-polsce/ [dostęp: 1.07.2016].

[22] Pietrzak G., Koncepcja systemu powietrznego wykrywania skażeń z wykorzystaniem środków bezpilotowych, praca dyplomowa, WAT, Warszawa 2016.

[23] Instytut Techniczny Wojsk Lotniczych, www.itwl.pl [dostęp: 1.06.2016].

[24] http://ilot.edu.pl/ilx-27/ [dostęp: 1.06.2016].

[25] Harmata W., Kłosowicz, S., Chałupczak M., Witczak M., Pirszel J., Problemy likwidacji skażeń powierzchni „wrażliwych", komunikat naukowy na Konferencję naukową Ochrona człowieka i środowiska naturalnego przed skażeniami, WIChiR, Warszawa 2014.
[26] http://www.phoenix-aerial.com/products/lidar-systems/scout-series/[dostęp: 1.06.2016].

[27] Instrukcja o powietrznym rozpoznaniu skażeń, MON, Chem. 306/82, Warszawa1982.

[28] http://fakty.interia.pl/galerie/kraj/zdjecie,ild,2174003,iAld,218218 [dostęp: 1.02.2017].

DR HAB. INŻ. WŁADYSŁAW HARMATA - w 1978 roku ukończył studia na Wydziale Chemii i Fizyki Technicznej Wojskowej Akademii Technicznej w Warszawie. Pracuje na stanowisku profesora na Wydziale Nowych Technologii i Chemii tej uczelni (specjalność - ekologia, likwidacja skażeń, ochrona przed skażeniami). Jest współautorem 9 patentów krajowych oraz 20 wdrożeń nowych opracowań do Sił Zbrojnych Rzeczypospolitej Polskiej (wyniki badań zostały opublikowane w około 340 oryginalnych pracach naukowych), a także autorem 6 monografii i podręczników akademickich.

GEN. BRYG. REZ. MAREK WITCZAK - w 1978 roku ukończył studia na Wydziale Chemii i Fizyki Technicznej Wojskowej Akademii Technicznej w Warszawie. Jako profesor wizytujący pracuje na Wydziale Nowych Technologii i Chemii tej uczelni (specjalność - ochrona przed skażeniami). Jest współautorem wielu opracowań z zakresu obrony przed bronią masowego rażenia. Specjalizuje się w wojskowych metodach rozpoznania skażeń chemicznych i radiologicznych ze szczególnym uwzględnieniem zagadnień dotyczących wykorzystania bezpilotowych aparatów rozpoznania i wykrywania skażeń. Zajmuje się też oceną sytuacji skażeń na podstawie systemów informatycznych dla potrzeb Sił Zbrojnych Rzeczypospolitej Polskiej.

PPOR. MGR INŻ. GRZEGORZ PIETRZAK - w 2016 roku ukończył indywidualne studia wojskowe na Wydziale Nowych Technologii i Chemii Wojskowej Akademii Technicznej (kierunek - chemia, specjalność - ochrona przed skażeniami). Interesuje się głównie technologiami bezpilotowymi i ich zastosowaniem w Siłach Zbrojnych Rzeczypospolitej Polskiej oraz materiałami ciekłokrystalicznymi i ich praktycznym zastosowaniem np. w detekcji skażeń. 